\title{
Steroids and Alzheimer's Disease: Changes Associated with Pathology and Therapeutic Potential
}

\author{
Yvette Akwa \\ "Disease and Hormones of the Nervous System", U1195 Inserm-Université Paris Saclay, \\ 80 rue du Général Leclerc, 94276 Kremlin-Bicêtre, France; yvette.akwa@inserm.fr
}

Received: 3 May 2020; Accepted: 3 July 2020; Published: 7 July 2020

check for updates

\begin{abstract}
Alzheimer's disease (AD) is a multifactorial age-related neurodegenerative disease that today has no effective treatment to prevent or slow its progression. Neuroactive steroids, including neurosteroids and sex steroids, have attracted attention as potential suitable candidates to alleviate AD pathology. Accumulating evidence shows that they exhibit pleiotropic neuroprotective properties that are relevant for $\mathrm{AD}$. This review focuses on the relationship between selected neuroactive steroids and the main aspects of $\mathrm{AD}$ disease, pointing out contributions and gaps with reference to sex differences. We take into account the regulation of brain steroid concentrations associated with human AD pathology. Consideration is given to preclinical studies in AD models providing current knowledge on the neuroprotection offered by neuroactive (neuro)steroids on major AD pathogenic factors, such as amyloid- $\beta(\mathrm{A} \beta)$ and tau pathology, mitochondrial impairment, neuroinflammation, neurogenesis and memory loss. Stimulating endogenous steroid production opens a new steroid-based strategy to potentially overcome AD pathology. This article is part of a Special Issue entitled Steroids and the Nervous System.
\end{abstract}

Keywords: neurosteroids; neuroactive steroids; sex difference; amyloid- $\beta$; tau protein; neuroprotection; mitochondria; neuroinflammation; memory; TSPO

\section{Introduction}

Alzheimer's disease (AD) is the most common dementia of the elderly and remains one of today's biggest public health challenges. The main pathological features observed in the AD brain are loss of synapses at early stages of the disease, senile plaques of amyloid- $\beta(A \beta)$ peptides, neurofibrillary tangles (NFTs) containing hyper and abnormally phosphorylated tau proteins leading to progressive neuronal loss (cortical atrophy). One form of the disease is familial AD, a very rare pure autosomal dominant disease with early onset before 65 years, which is caused by mutations in amyloid precursor protein (APP), presenilin-1 (PS1) or presenilin-2 genes all connected to $A \beta$ accumulation. The other form is sporadic $\mathrm{AD}$ or late-onset $\mathrm{AD}$ which accounts for the majority of $\mathrm{AD}$ cases and is caused by environmental factors and genetic predisposition [1]. Soluble $A \beta$ oligomers impact synaptic plasticity early in the pathological process [2,3]. Progressive synaptic dysfunction then impairs episodic/recent memory followed by slow decline in other cognitive abilities, accompanied by neuropsychiatric symptoms including apathy, anxiety and depression [4,5]. A large body of evidence suggests that there is a long prodromal infraclinical phase during which pathological changes begin decades before plaques and tangles are formed [6].

Besides aging, which is considered the greatest risk factor of $\mathrm{AD}$, apolipoprotein (ApoE) $\varepsilon 4$ genotype and sex are critical AD risk factors $[7,8]$. Several neurobiological pathways also contribute to neurodegeneration and cognitive impairment, including mitochondrial dysfunction and oxidative stress, neuroinflammations that are pertinent targets of neuroactive neurosteroids. 
At present, no medication exists for $\mathrm{AD}$ despite intensive research on neuropathology, symptoms and mechanisms. Symptomatic treatments have had either little or no effect, so new strategies mostly aim at reducing the overall burden within the AD brain. Among them, the exogenous administration of neuroactive steroids or the modulation of their endogenous production can potentially provide therapeutic benefits, particularly in the preclinical stage before the neurodegenerative disease process is established. Endogenous neuroactive steroids include steroids that are synthesized de novo in the central nervous system (CNS) as neurosteroids, hormonal steroids generated from endocrine glands and transported into the brain from circulation, and steroids synthesized in the brain from gonadal steroids. Significant alterations in their concentration and metabolism are observed in the blood, brain and cerebrospinal fluid (CSF) samples of AD patients. In addition, neuroactive steroids, independent of their central or peripheral origin, regulate a wide range of key physiological processes in the CNS by regulating gene expression, neuronal excitability and signaling. These data have provided the basis for their neuroprotective, neuroregenerative and neuropsychopharmacological effects that may be pertinent for AD treatment [9-11].

The aim of this review is to summarize the current research on the levels of steroids and biosynthetic enzymes in the AD brain and their relationship with critical pathogenic factors in various AD models, including human neuroblastoma cell lines, rats and transgenic mice developing $\mathrm{A} \beta$ or tau pathology. Emphasis is on steroid specificity and, when possible, on sex differences. The focus is on key neuroactive steroids, namely the neurosteroids pregnenolone (PREG) progesterone (PROG), alloprogregnanolone, dehydroepiandrosterone (DHEA), the sulfated steroids pregnenolone sulfate (PREGS) and dehydroepiandrosterone sulfate (DHEAS), as well as the sex-steroid testosterone and $17 \beta$-estradiol (E2).

\section{Dysregulated Brain Steroidogenesis and Steroid Concentrations Associated with AD}

\subsection{Steroidogenesis in the Human Brain}

Since human brain steroidogenesis can differ from that of laboratory animals, investigating steroid and enzyme levels also requires samples from AD patients and age- and gender-matched nondemented controls. Moreover, blood steroid levels do not necessarily adequately reflect brain steroid concentrations and enzyme activity. All steroids are synthesized from cholesterol either de novo from acetate in the endoplasmic reticulum or imported from density lipoproteins derived from dietary sources. Steroidogenic pathways are well characterized in rodent brains [12]. The human brain also has the capacity to synthesize steroids. Evidence supports the existence of key steroidogenic enzyme mRNAs, protein or activity in brain samples. The biosynthesis and metabolism of neurosteroids and sex steroids in the human brain is depicted in Figure 1. The cytochrome P450side-chain cleavage (P450scc), encoded by the Cyp11A1 gene, is involved in the initial and rate-limiting step inside mitochondrial matrix that converts cholesterol to pregnenolone (PREG), the precursor of all steroids [13]. P450scc mRNA was found in several areas, i.e., the temporal and frontal neocortex, hippocampus, corpus callosum, thalamus, caudate nucleus and amygdala $[14,15]$. The corresponding protein was detected in the cerebellar white matter by immunochemistry [16]. The $3 \beta$-Hydroxysteroid dehydrogenase- $\Delta 5 \rightarrow \Delta 4$ isomerase ( $3 \beta-\mathrm{HSD})$ is a membrane-bound enzyme located in the mitochondria and endoplasmic reticulum. It catalyzes the production of PROG from PREG and androstenedione from DHEA. In humans, type 1 and type $23 \beta$-HSD isoforms are characterized. Both $3 \beta$-HSD isoform mRNAs were present in the corpus callosum, hippocampus and amygdala, with type 2 at higher levels than type 1 [15]. PROG can act in its native form and/or after transformation into active metabolites. In the CNS, the $5 \alpha$-reductase converts PROG to $5 \alpha$-dihydroprogesterone ( $5 \alpha$-DHP) which is further reduced by the $3 \alpha$-hydroxysteroid dehydrogenase ( $3 \alpha$-HSD) to the potent $\gamma$-aminobutyric acid type $\mathrm{A}\left(\mathrm{GABA}_{\mathrm{A}}\right)$ receptor-acting neurosteroid $3 \alpha, 5 \alpha$-tetrahydroprogesterone $(3 \alpha, 5 \alpha-\mathrm{THP})$ also named allopregnanolone. Two forms of $5 \alpha$-reductase exist, with type 1 being the major isoform widely distributed in the human brain. Type $15 \alpha$-reductase mRNA and activity are located in the temporal neocortex, subcortical white 
matter and hippocampus [14,17]. The $3 \alpha$-HSD belongs to the aldo-keto reductase (AKR) superfamily with $A K R_{1} C_{1}, A K R_{1} C_{2}$ and $A K R_{1} C_{3}$ isoenzymes expressed in the human brain [18]. $A K R_{1} C_{2}$ (type 3 $3 \alpha$-HSD) metabolizes $5 \alpha$-DHP to allopregnanolone while $\mathrm{AKR}_{1} \mathrm{C}_{1}$ metabolizes allopregnanolone to its $20 \alpha$-reduced metabolite thus reducing neurosteroid concentration in the brain $[19,20] . \mathrm{AKR}_{1} \mathrm{C}_{3}$ ( $3 \alpha$-HSD type 2) mRNA was characterized in the temporal neocortex and subcortical white matter [17]. Interestingly, mRNA expression of $3 \alpha$-HSD was much higher than that of $5 \alpha$-reductase, suggesting that $5 \alpha$-reduction is the rate-limiting step in the synthesis of allopregnanolone. The neurosteroids PREG and PROG can also be converted by the cytochrome P450c17. This $17 \alpha$-hydroxylase/17, 20-lyase (CYP17) converts both steroids into DHEA and androstenedione, respectively. The level of P450c17 mRNA was higher in the corpus callosum and amygdala than the hippocampus and cerebellum [15]. With respect to sulfated steroids, human $3 \beta$-hydroxysteroid sulfotransferases $(3 \beta$-HSTs) are present in the human brain and SULT2B1 is selective for the sulfonation of $3 \beta$-hydroxysteroids, such as PREG and DHEA [21,22]. Only SULT2B1b (not SULT2B1a) transcripts were detected throughout the human brain regions with the frontal/temporal lobes and thalamus expressing the highest levels [22].

The $17 \beta$-hydroxysteroid dehydrogenases (17 $\beta$-HSD) and aromatase are essential in the end steps of neurosteroidogenesis. The 17 $\beta$-HSD is involved in the interconversion of androstenedione to the strong androgenic testosterone, and DHEA to $17 \beta$-androstenediol. The expression of mRNAs encoding type $1,3,4,5,7,8$ and 10 isoforms of $17 \beta-H S D$ was detected in the human temporal lobe [14,23]. The in vitro activity of $17 \beta$-HSD promoted the synthesis of testosterone in the cerebral cortex and subcortical white matter [24] and of $17 \beta$-androstenediol in several human brain regions, including the hippocampus, amygdala striatum and cerebellum [25]. 17 $\beta$-HSD10, known to be involved in the inactivation of many endogenous steroids, was found to be highly expressed in the human hippocampus, hypothalamus and amygdala [26]. At last, the cytochrome P450 aromatase, encoded by Cyp19 gene, is another key enzyme for the aromatization of testosterone to E2. Aromatase mRNA expression was detected in the frontal cortex, hippocampus, subcortical white matter, thalamus and hypothalamus [14,27-29]. Aromatase activity was demonstrated in human frontal and temporal brain regions [30,31], hippocampus, pons, thalamus and hypothalamus [28,32]. Notably, $17 \beta$-HSD plays a critical role in the bidirectional reactions between E2 and the weak estrogenic compound estrone E1, and the $17 \beta$-HSD type 1 catalyzed the reduction of E1 to E2 [33].

To date, no sex-specific differences have been identified for all the enzymes cited above except for P450scc, for which mRNAs levels were higher in adult women than men, particularly in the temporal lobe, frontal lobe and hippocampus [34,35]. The steroid biosynthetic pathway and steroid enzyme location in the human brain are depicted in Figure 1.

\subsection{Changes in Neurosteroid and Biosynthetic Enzyme Levels}

Increasing evidence suggests that dysregulation of steroid endogenous concentrations and their biosynthetic enzymes play a role in neurological diseases, including $\mathrm{AD}[36,37]$. It is to be noted that brain steroid levels reflect not only hormonal production and metabolism from endocrine glands, but also the local neurosteroidogenesis. There is a very limited or no recent data addressing brain steroid levels in AD or control subjects. Therefore, we choose to cite the few initial studies that described substantial changes in neurosteroid levels in postmortem brain samples of AD patients as compared to cognitively intact nondemented subjects. Those investigations used reliable methodologies, coupling solid phase extraction, purification by high performance liquid chromatography and identification by gas chromatography-mass spectrometry (GC-MS) instead of radioimmunoassay. Indeed, the latter represents an important limitation in analyzing low concentrations of steroids in brain tissue samples, due mainly to the lack of specificity and availability of antibodies [38]. Numerous neurosteroids have been quantified in postmortem human brain specimens. Substantial changes in their levels in the AD brain (Figure 2A) suggest that disequilibrium in neurosteroid pathways have a role in $\mathrm{AD}$ pathogenesis. The regulation of steroid levels by $A \beta$ burden in vitro and in vivo is described (Figure $2 B$ ). 


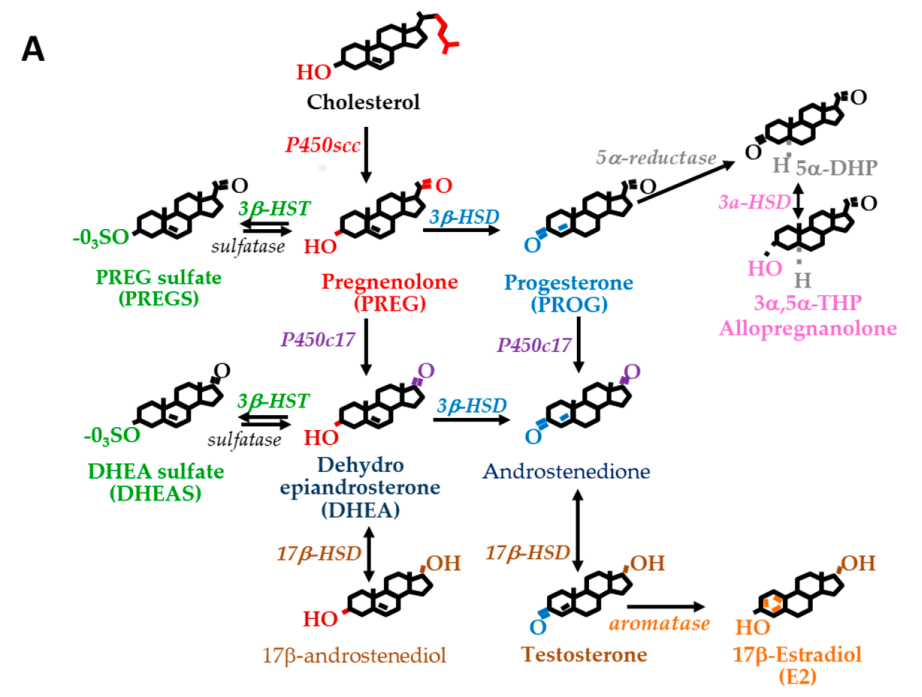

B

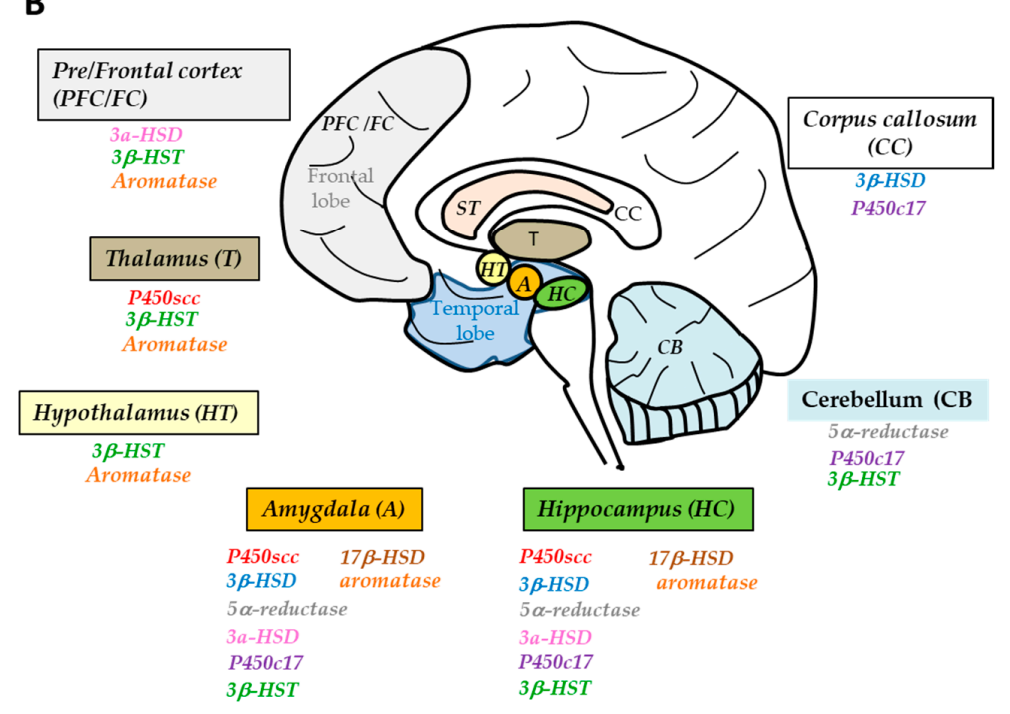

Figure 1. Neurosteroid and sex steroid biosynthetic pathway in the human brain. (A) The main steps of neuroactive steroid synthesis are shown. The initial and limiting step involves P450scc activity catalyzing the metabolism of cholesterol to pregnenolone (PREG), the precursor of all neurosteroids and sex steroids. Then, PREG is transformed to progesterone (PROG) and its $5 \alpha$-reduced and $5 \alpha, 3 \alpha$-reduced metabolites ( $5 \alpha$-DHP and allopregnanolone). These steps involve $3 \beta$-HSD and the $5 \alpha$-reductase $/ 3 \alpha$-HSD complex enzymes. PREG and PROG are precursors of DHEA and androstenedione, respectively. PREGS and DHEAS are produced from PREG and DHEA by sulfotransferases and can in turn be desulfated by sulfatases. The so-called sex steroids are testosterone produced from androstenedione by $17 \beta-H S D$ activity and E2 from testosterone aromatization. (B) Location of steroidogenic enzyme in the human brain regions. Enzyme mRNA, protein and activity are present, except for P450scc

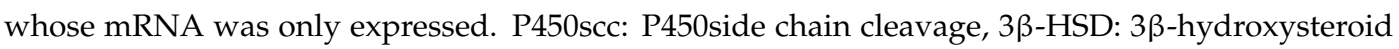
dehydrogenase- $\Delta 5$ ( $\Delta 4$ isomerase, $3 \alpha$-HSD: hydrosteroid dehydrogenase, $3 \beta$-HST: $3 \beta$-hydroxysteroid sulfotransferase, 17 $\beta$-HSD: $17 \beta$-hydroxysteroid dehydrogenase $5 \alpha$-DHP: $5 \alpha$-dihydroprogesterone; $3 \alpha, 5 \alpha$-THP: $3 \alpha, 5 \alpha$-tetrahydroprogesterone.

PREGS and DHEAS were found to be significantly lower in aged AD patients than age-matched nondemented controls, especially in the striatum, cerebellum and hypothalamus, and negatively correlated with high levels of cortical $A \beta$ and phosphorylated tau proteins [39]. These reduced PREGS and DHEAS levels suggested that the $3 \beta$-HST enzyme involved in their biosynthesis was reduced. However, Calan et al. 2016 [40] showed that toxic doses of A $\beta$ significantly increased PREGS cellular 
levels in a time-dependent manner in SH-SY5Y cultured cells as compared to control cells (Figure 2A). This enhanced steroid production was interpreted as a result of self-defense probably to overcome harmful effects of $\mathrm{A} \beta$.

The levels of free neurosteroids are also regulated in AD brain regions. Decreased PREG and DHEA concentrations were noticed in several brain areas of aged AD patients albeit not significantly different than controls. Similar steroid levels were found between regions in the AD group, including frontal cortex, striatum, amygdala and hippocampus [39]. In the studies by Marx et al. 2006 and Naylor et al. 2010 [41,42], high DHEA and PREG concentrations were observed in the prefrontal and temporal cortices of $\mathrm{AD}$ patients and tended to be positively correlated with Braak and Braak stage [41]. Similarly, in SH-SY5Y neuronal cells, treatment with $A \beta$ peptides $\left(A \beta_{25-35}, A \beta_{1-40}\right.$ or $\left.A \beta_{1-42}\right)$ at toxic doses significantly enhanced PREG levels [40] (Figure 2B). PREG levels were higher in the group treated with $A \beta_{25-35}$ than the two others and proportionate to cell cholesterol content. The author suggested that the effect of $A \beta$ on PREG levels might be a result of self-defense. PREG concentration also significantly increased in the hippocampus on days 7 and 12 following bilateral injection of $A \beta_{25-35}$ in the rat CA1 region [43].

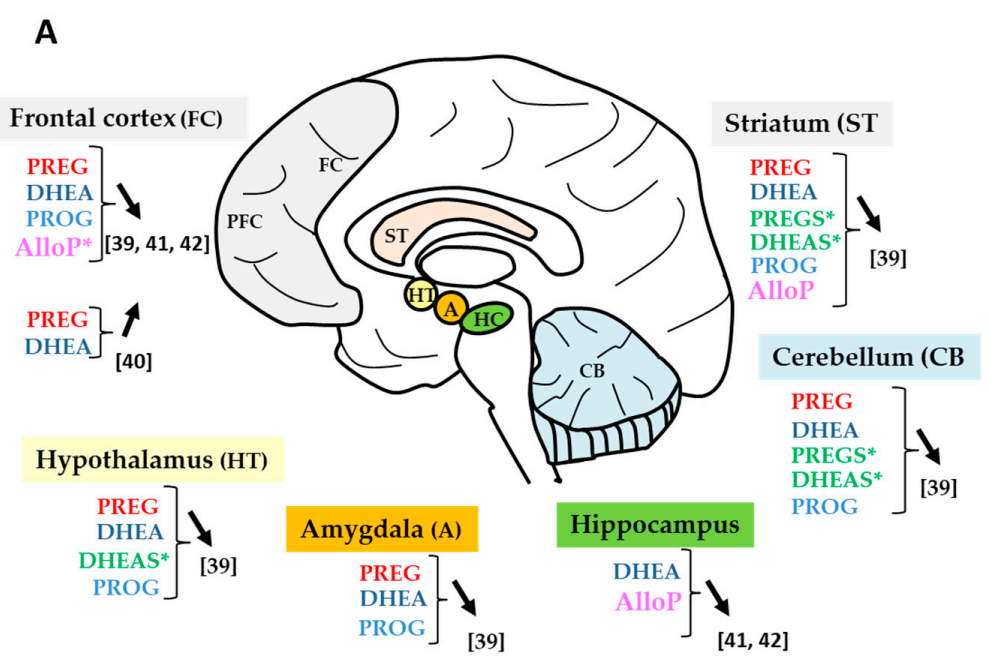

B

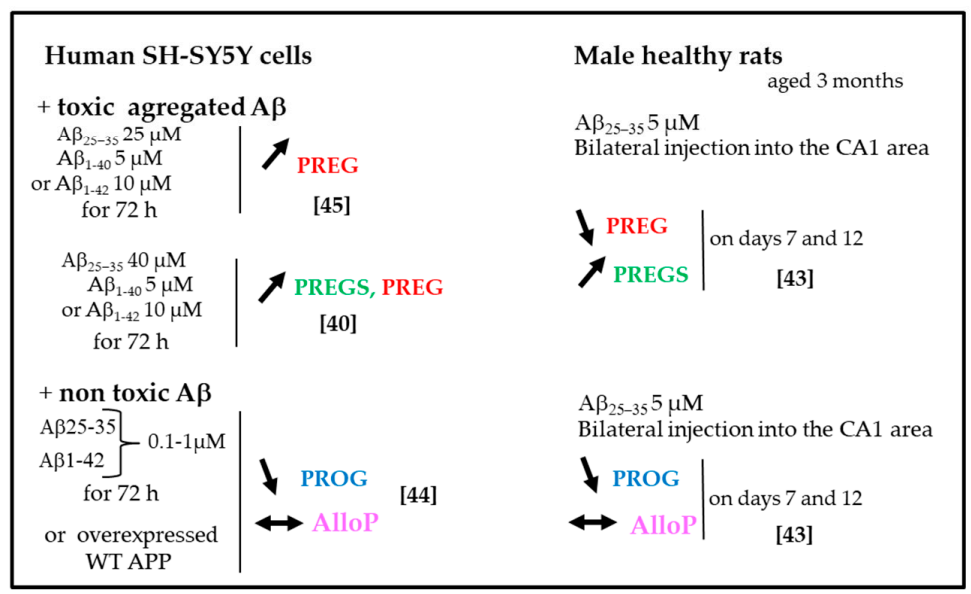

Figure 2. Change in endogenous neurosteroid levels. (A) In the AD brain. A general trend of lower levels of neuroactive steroids was observed in different brain regions of $\mathrm{AD}$ patients than nondemented controls ( ${ }^{*}$ significant decrease in steroid levels). Participants were women and men with mean age $86 \pm 2$ years [39], $77.3 \pm 2$ years [42] or only men with median age 83.0 years [41]. (B) Under in vitro and in vivo $A \beta$ burden conditions. $\downarrow$ : decrease, $\uparrow$ : increase, $\leftrightarrow$ : no change vs. $A \beta$. 
Lower PROG concentrations were quantified in several brain regions (frontal cortex, striatum, hypothalamus and hippocampus) of AD patients than controls, with no significant difference between the groups possibly due to the low number of patients [39]. In rats, PROG levels were significantly reduced in the hippocampus and prefrontal cortex following prolonged bilateral administration of $A \beta_{25-35}$ into the CA1 region [43]. Similarly, the synthesis of PROG from PREG was reduced in neuronal cell cultures under A $\beta$ burden conditions [44,45] (Figure 2B).

Allopregnanolone was found to be significantly decreased in the prefrontal and temporal cortices of $A D$ patients [41,42]. In contrast to $P R O G$, allopregnanolone content was unchanged in the hippocampus of $A \beta$-treated rats nor was its production in SH-SY5Y cells displaying A $\beta$ pathology [43-45]. These data suggest that $A \beta$ may target only specific steroidogenic enzymes, decreasing $3 \beta-H S D$ activity to reduce PROG without affecting $3 \alpha$-HSD involved in allopregnanolone. Thus, steroid changes in AD brain and those under $A \beta$ burden conditions appear inconsistent. The direct effects of $A \beta$ peptides on steroid enzyme expression and activity need further evaluation in several in vivo models of $A \beta$ pathology. The mechanism by which allopregnanolone decreased in AD brain remains unclear. He et al. 2005 [46] demonstrated that the human brain $17 \beta$-HSD type 10 can catalyze allopregnanolone oxidation to yield $5 \alpha$-DHP. High levels of $17 \beta$-HSD10 were quantified in activated astrocytes of several brain regions with $\mathrm{AD}$ pathology, including the hippocampus, hypothalamus and amygdala [46]. The upregulation of $17 \beta$-SHD activity may then lead to local reduced allopregnanolone levels in AD brain. In fact, discrepancies were observed in 17 $\beta$-HSD type 10 levels that were either upregulated in the late stages of the AD brain [26] or unchanged [47]. This mitochondrial enzyme may also interact with soluble or aggregated $A \beta[48,49]$. In addition, it is unclear whether allopregnanolone reduction in the AD brain is related to $A \beta$ accumulation per se. The decrease in allopreganolone levels in the AD brain was found inversely correlated to Braak and Braak stage, reflecting neuropathological disease severity [41,42]. Thus, the allopregnanolone content in the AD brain may rather have relevance in tau pathology since Braak and Braak staging focus on NFTs. Interestingly, Luchetti et al. 2011 [47] detected high levels of $3 \alpha$-HSD type 3 mRNA in cortical astrocytes starting from Braak stage 3. Although an enhancement in allopregnanolone synthesis was not demonstrated, it may be seen as a rescue mechanism early in the disease process aimed at promoting brain protection.

The relationship between pathological tau and neuroactive steroids remains elusive. Only one investigation stated that tau with pathogenic mutation P301L associated with frontotemporal dementia (FTD) had no impact on neurosteroid synthesis: neither the production of PROG nor allopregnanolone was modified in SH-SY5Y cells stably transfected by the mutant P301L tau and incubated with PREG as compared to native cells [44]. Further studies are required to deeply explore the relationship between pathological forms of tau (P301S mutant, oligomers or fibrillary tau) and neurosteroid concentrations.

\subsection{Changes in Sex Steroids and Biosynthetic Enzyme Levels}

Changes in sex steroid levels are also relevant to AD. The age-related decrease in brain levels of testosterone in men and E2 in women during menopause have been associated with greater risk of developing $\mathrm{AD}[37,50]$. Brain testosterone levels were found to be lower in men with $\mathrm{AD}$ than control subjects. Rosario et al. 2011 [50] mentioned that testosterone was regulated according to age and disease stage (Figure 3A). It was reduced only in the brains of men aged 60-79 years diagnosed with $\mathrm{AD}$ at mild stages but not in those over 80 , suggesting that testosterone loss in the brain occurs early in the disease process. Indeed, brain testosterone was inversely correlated with soluble $A \beta$ levels [50]. Interestingly, Type $117 \beta-H S D$ mRNA progressively increased in the AD prefrontal cortex, starting from Braak stages 3-4 suggesting an early increase in testosterone synthesis in relation with tau pathology that may culminate in Braak stages 5-6 [47]. In male 3xTg-AD mice, an increase in brain testosterone with age was seen in the hippocampus (Figure 3B) associated with the expression of the early tau pathologic conformational marker Alz50 and extra-neuronal A $\beta$ deposition, with no change in the androgen receptor level [51]. 
In $\mathrm{AD}$ women, the regulation of brain E2 is also age-dependent (Figure $3 \mathrm{~A})$. Women with $\mathrm{AD}$ aged 80 years and older exhibited significantly lower brain E2 than age-matched nondemented controls [50,52] (Figure 3A). Surprisingly, aromatase expression increased from mild to moderate stages, particularly in the prefrontal cortex and hippocampus $[47,53]$. This aromatase increase is even higher in the later stages and occurred in both astrocytes [50] and neurons [53].

Again, these results point out the importance of the disease stage in the evaluation of steroid and enzyme levels in the AD brain. The enhancement of testosterone levels in the late stage of $\mathrm{AD}$ pathology as well as the upregulation of aromatase and 17 $\beta$-HDS type 1 (which can also convert estrone to E2) to enhance E2 synthesis could be viewed as part of a compensatory neuroprotective mechanism. Consistent with this idea, brain injury in rodents rapidly upregulated aromatase enzyme expression in glial cells at the injury site suggesting that increased E2 levels may afford protection in injured neurons [54,55]. An upregulation of E2 synthesis was observed in SH-SY5Y neuronal cells with A $\beta$ burden [44,45] (Figure 3B). E2 significantly increased in the prefrontal cortex and in the hippocampus after bilateral infusion of $A \beta$ into the male rat hippocampus [43] (Figure 3B). Surprisingly, in aged $3 x T g-A D$ mice, the increase in brain testosterone was not associated with a concomitant increase in brain E2. Contrariwise, brain E2 did not change with age in both males and females [51].

A

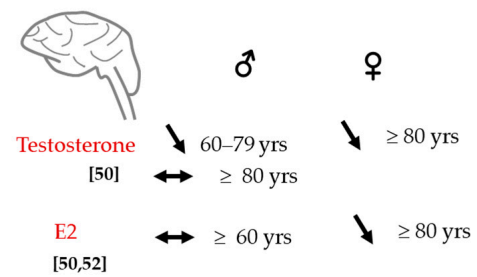

B

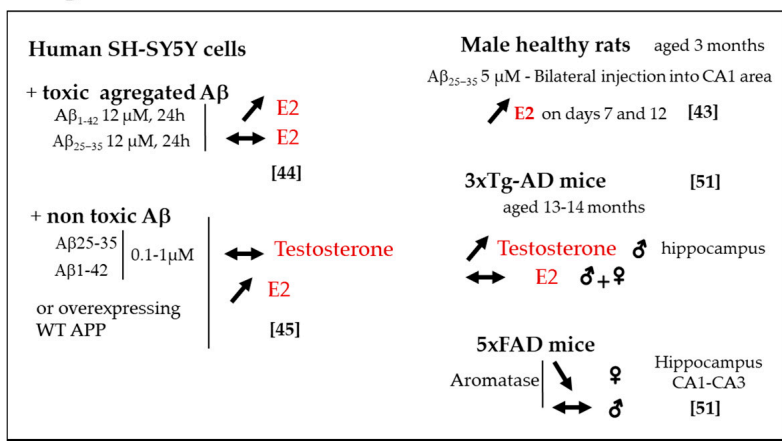

Figure 3. Change in endogenous sex-steroid levels. (A) In the AD brain compared to nondemented controls. (B) Under in vitro and in vivo A $\beta$ burden conditions. $\downarrow$ : decrease, $\uparrow$ : increase, $\leftrightarrow$ : no change vs. $A \beta$.

\subsection{Sex Difference in Neuroactive Steroid Levels}

Sex differences have been noted in AD but remain debated. Most studies suggest that women have greater frequency and lifetime risk than men. There is also mixed opinion concerning prevalence and incidence rates, and disease course [56-59]. Sex difference in the occurrence and distribution of $A \beta$ plaques in the brain or CSF A $\beta$ concentrations is unknown. Evidence of any impact of sex on brain tau hyperphosphorylation and NFTs or CSF tau levels is not established [60]. Sex differences in neuroactive steroid levels may be important to consider in AD, yet are poorly explored. The study by Corbo et al. 2014 [61] showed a direct influence of CYP17 genotypes on AD susceptibility and age of onset mainly in men. The study of Rosario et al. 2011 [50] revealed sex-specific brain levels of testosterone and $\mathrm{E} 2$ in $\mathrm{AD}$ patients (Figure $3 \mathrm{~A}$ ). In postmortem AD brain samples, reduced testosterone and E2 levels were noted in women older than 80 years, while only testosterone decreased in men aged 60-79 years. 
An earlier report from the same group indicated that E2 brain levels did not decrease with age in men and were unaffected in AD brain at any stage of the pathology [62]. Furthermore, the aromatase gene CYP19A1 polymorphisms appeared to be exclusively associated with AD risk in women and not in men $[63,64]$. Therefore, brain E2 and aromatase levels do not seem to be linked to AD status in men. It is interesting to note that sex-specific differences in the aromatase were demonstrated in transgenic mice that early express A $\beta$ pathology (Figure 3B) [53]. The expression of aromatase mRNA and protein in the hippocampus was similar in male 5xFAD mice (that express human APP and PSEN1 transgene with a total of five mutations) and controls, whereas it was significantly lower in 5xFAD females [53]. Therefore, the contribution of E2 to the sex-specific effect seen in AD may primarily be related to $\mathrm{A} \beta$ pathology among $\mathrm{AD}$ etiologies. The regulation of $\mathrm{E} 2$ production and related enzymes (aromatase, $17 \beta-\mathrm{HSD}$ ) in the brain of AD women and men may deserve further investigation that needs to take into account age, sex, and disease state.

Direct access to the human brain remains challenging as compared to CSF. Changes in CSF neuroactive steroids might reflect changes in the brain and be a good alternative to better understand their role in AD. Changes in CSF neuroactive steroids were previously observed in humans with no brain disorders [65-67], but they are scarce in AD. A lower CSF E2 level was found in AD female patients compared to nondemented ones [68] and this corroborates the lower brain E2 in AD women as compared to controls [50,52].

\section{Steroids and Genetics of Late-Onset AD}

The only strong and well-established genetic risk factor for the development of late-onset AD is the inheritance of the APOE- $\varepsilon 4$ allele (for review [69]). ApoE is a multifunctional protein that binds to the low-density lipoprotein receptor family and therefore plays a central role in maintaining cholesterol/lipid homeostasis in the brain [70]. Recent studies provide evidence of a connection between abnormal cholesterol metabolism by ApoE4 and AD pathology. Impaired efflux of cholesterol in $\mathrm{APOE}-\varepsilon 4$ neurons contributes to its intracellular accumulation and $A \beta$ increase [71]. Since cholesterol is the precursor of all steroids, associations with APOE4 and cholesterol-derived steroids could be considered. However, only a few reports have investigated this issue. A significant decrease in allopregnanolone levels was observed in the temporal cortex of patients positive for the APOE- $\varepsilon 4$ allele compared to patients not carrying it [42]. Sex differences in the risk of AD are also modified by APOE genotypes. The APOE- $\varepsilon 4$ risk of developing AD was thought to be greater in women as compared to male carriers [72,73]. In fact, greater risk of late-onset AD was evident in APOE- $\varepsilon 4$ homozygote females, while increased risk of early-onset AD was evident in APOE- $\varepsilon 4$ homozygote males [8,72]. Increased APOE-related risk in women seems to be associated with tau pathology [72]. Why APOE- $\varepsilon 4$ gene confers higher risk in women is unclear. Whether E2 levels in APOE- $\varepsilon 4$ carrying women are directly or indirectly linked to AD risk and severity is also uncertain. In men, E2 was lower in APOE- $\varepsilon 4$ carriers with $\mathrm{AD}$ than controls, and testosterone was lower only in AD men without APOE- 44 [74]. The roles of endogenous steroid levels as factors relevant to APOE- $\varepsilon 4$ carriers at risk of AD remain to be fully characterized.

\section{Protective Effects of Neuroactive Steroids on AD-Like Neuropathology}

Endogenous neuroactive (neuro) steroids are among the most potent modulators of CNS functions. The changes in their levels in the AD brain suggest that they may be key modulators of AD-like neuropathology. They can target several important landmarks of AD pathology, via a variety of mechanisms including prevention of apoptosis, oxidative stress, mitochondrial dysfunction, synaptic loss and regulation of intracellular survival signaling pathways.

\subsection{Amyloid- $\beta$ Pathology}

The $\mathrm{A} \beta$ protein is a crucial initiator that triggers the pathological events leading to $\mathrm{AD}$ through accumulation and aggregation within the CNS. It is a small protein composed of 39-43 amino acids 
generated by sequential cleavage of human amyloid precursor protein by $\beta$ - and $\gamma$ - secretases. Its two major forms are $A \beta_{1-40}$ and $A \beta_{1-42}$ with the latter being more prone to aggregate in AD patients. The $A \beta_{25-35}$ fragment is a biologically active $C$-terminal region of $A \beta_{1-42}$. Aggregated $A \beta$ peptides have harmful properties, but proof implicates soluble oligomeric $A \beta$ as the primary noxious form. $A \beta$ toxicity to neurons promotes a myriad of detrimental cellular events associated with neuronal death including, for instance, pore formation, oxidative stress, lipid peroxidation, mitochondrial dysfunction, neuroinflammation, loss of synapses and disruption of the cytoskeleton, among others (for reviews [2,75]). All A $\beta$ forms are convenient tools for in vitro and in vivo experimental models of $\mathrm{A} \beta$ pathology associated with AD. Several steroids illustrated their capacity to protect cells from death induced by these peptides and, the way they achieve their neuroprotective effects is elucidated most of the time. We may note that, for a given steroid, results may appear controversial depending on the $A \beta$ form, cell type, dose and duration of steroid treatment used. Inversely, A $\beta$ peptides can affect steroid levels in neuronal cells.

\subsubsection{Effects of Neurosteroids on $A \beta$ Toxicity}

The effects of neurosteroids on A $\beta$ toxicity are summarized in Figure 4. Regarding PREG and PREGS, very few studies have reported their regulatory effects on $A \beta$-induced neuronal toxicity. PREG protected mouse hippocampal (HT-22) and rat pheochromocytoma (PC-12) cell lines in a dose-dependent and significant manner against $A \beta_{25-35}$-induced cell death $[76,77]$, but the molecular target(s) for its action awaits identification.

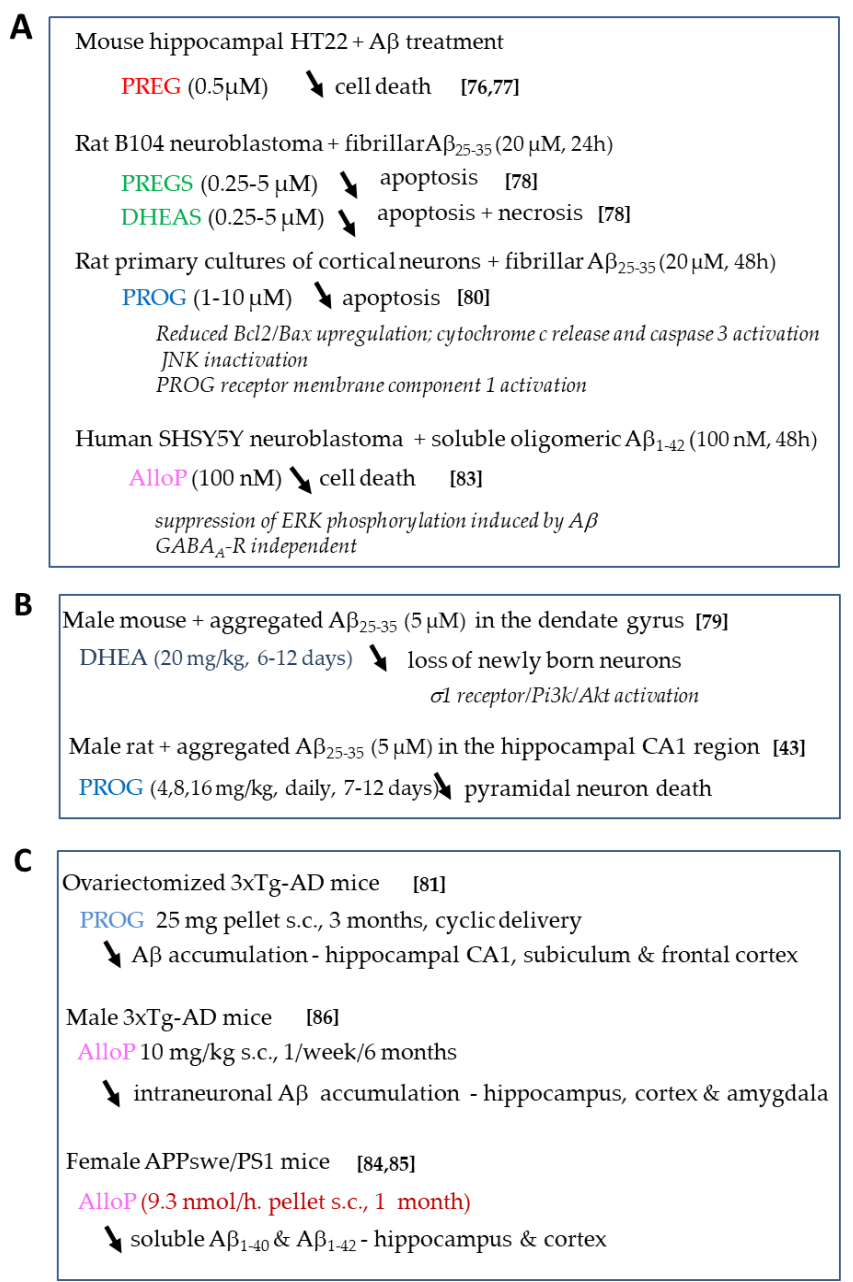

Figure 4. Protective neurosteroid treatment on $A \beta$ toxicity. (A) in vitro (B) in vivo after $A \beta$ administration in rodent hippocampus and (C) in vivo in transgenic mouse models of AD. 
Interestingly, PREGS treatment differentially regulated neuronal cell survival in in vitro $\mathrm{A} \beta$-induced $\mathrm{AD}$ models. One study indicated that it did not have any effect on the $\mathrm{A} \beta_{25-35}$-induced decrease in PC12 cell viability [77]. More recently, we observed that it significantly and dose-dependently counteracted the reduced cell viability induced by $\mathrm{A} \beta_{25-35}$ in rat B104 neuroblastoma cells by preventing the cells from entering late apoptosis [78]. DHEAS was also capable of significantly attenuating $\mathrm{A} \beta_{25-35}$-induced toxicity, by preventing the cells from entering both late apoptosis and necrosis [78] (Figure 4A)]. DHEA neuroprotection was observed against neurite growth impairment and loss of newborn neurons caused by $A \beta_{25-35}$ infusion in the mouse dentate gyrus. This effect involved a sigma1 receptor-dependent activation of PI3K-Akt-mTOR signaling pathways that play a role in the regulation of apoptosis and cell growth [79] (Figure 4B).

PROG has also been shown as an effective neuroprotectant in AD models (Figure 4). Several studies stated that PROG exerts neuroprotective effects against $A \beta_{25-35}$-induced toxicity in vitro and in vivo (Figure 4A,B). PROG significantly and dose-dependently improved neuronal survival in primary cultured rat cortical neurons treated by $\mathrm{A} \beta_{25-35}$ [80]. This effect implicated a decrease in the upregulation of the apoptotic marker Bax/Bcl2 ratio that signals the loss of mitochondrial membrane potential and downstream caspase- 3 activation. In addition, the mitochondrial PROG receptor membrane component 1 was activated and the c-Jun $\mathrm{N}$-terminal kinase pathway inactivated (Figure 4A). The classic PROG receptor was also partly involved. In vivo, PROG treatment reduced the decrease in hippocampal cell number induced by $A \beta_{25-35}$ injection into the rat hippocampal CA1 region [43] (Figure 4B). The delivery procedure had a differential impact on the effect of PROG on $\mathrm{A} \beta$ intraneuronal accumulation. Indeed, in ovariectomized triple transgenic AD mice 3xTg-AD (bearing the human $\mathrm{APP}_{\mathrm{SWE}}, \mathrm{Tau}_{\mathrm{P} 301 \mathrm{~L}}$, and $\mathrm{PS}_{\mathrm{M} 146 \mathrm{~V}}$ genes linked to $\mathrm{AD}$ and FTD), PROG cyclic delivery significantly attenuated $A \beta$ accumulation in different brain regions (Figure $4 C$ ), whereas PROG continuous treatment for three months was devoid of any action [81]. These findings highlighted the importance of timing and duration of steroid administration. Additional studies are needed to clarify the mechanisms underlying different PROG treatment outcomes. One possible mechanism of PROG positive result may involve enhancement of $A \beta$ clearance factors [82].

The neuroprotective effects of allopregnanolone against $A \beta$ pathology have also been demonstrated. Allopregnanolone prevented the neurotoxicity resulting from $A \beta_{1-42}$ exposure in SH-SY5Y and primary cortical neurons via the suppression of extracellular signal-regulated kinase phosphorylation induced by $A \beta$ and independently of $\mathrm{GABA}_{\mathrm{A}}$ receptor activity [83] (Figure $4 \mathrm{~A}$ ). Discrepancies were noted in the in vivo effects of allopregnanolone treatment on $A \beta$ levels across $A D$ transgenic mouse models that depended on the duration, frequency and time window of treatment. For instance, short chronic allopregnanolone treatment in two models of autosomal dominant AD resulted in increased soluble A $\beta$ levels in the brain of female APPswe/PS1 mice but not in female APPswe/Arc (Figure 4C) [84,85]. This difference might be explained by the distinct contribution of mutated PS1 and Arc genes in regulating A $\beta$ production. Whether these data have any relevance to human late-onset $\mathrm{AD}$ is open. In male 3xTg-AD mice, an allopregnanolone regimen of one/week/six months at an early stage of pathology progression showed the highest efficacy on $A \beta$ reduction as compared to three/week/three months and one/month [86]. Therefore, the therapeutic time window is important for steroid efficacy and intra- not extraneuronal $A \beta$ seems to be a critical target for allopregnanolone benefits.

\subsubsection{Effects of Sex Steroids on $A \beta$ Toxicity}

Androgens may contribute to slowing down AD. Gonadectomy increased A $\beta$ levels and androgens exerted a substantial inhibition of $A \beta$ accumulation in male AD mouse models [87,88]. Testosterone treatment of gonadectomized 3xTg-AD mice prevented the increase of $A \beta$ accumulation in several brain regions by direct activation of the androgen receptor $[88,89]$. E2 treatment was partially effective in reducing $A \beta$ in these mice. Both testosterone and E2 reduced tau hyperphosphorylation [89], suggesting a role of testosterone via aromatization (Figure 5A). 

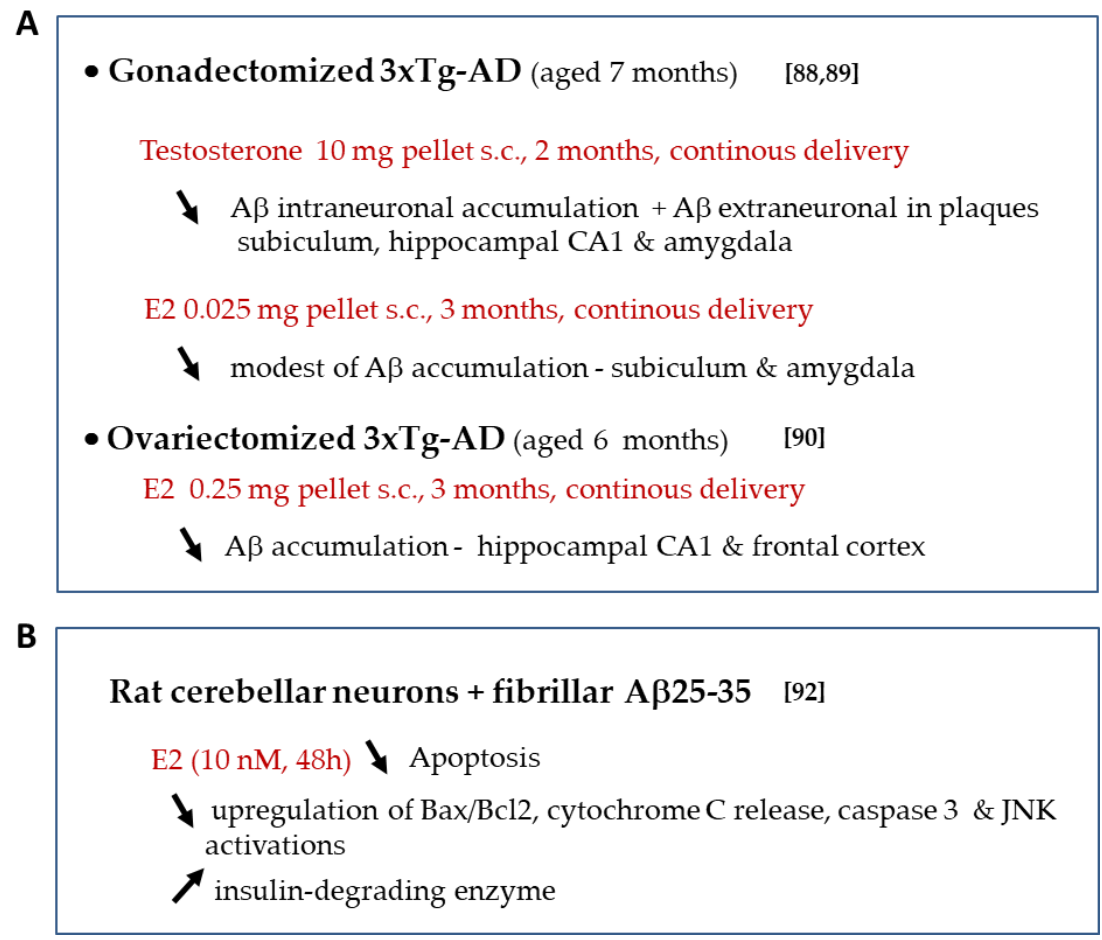

Figure 5. Sex-steroid treatment on $A \beta$ toxicity in vivo (A) and in vitro (B). $\downarrow$ : decrease, $\uparrow$ : increase, $\leftrightarrow$ no change.

The role of $E 2$ in reducing $A \beta$ accumulation and associated toxic events has been investigated [90]. In ovariectomized 3xTg-AD, E2 treatment entirely prevented $A \beta$ accumulation in specific brain regions [91] (Figure 5A). E2 protective effect was partially attenuated by PROG suggesting that these steroids act in part via a common mechanism that yet needs clarification. E2 also prevented the $A \beta$-induced apoptosis in rat cerebellar granule cells [92] (Figure 5B). The protective effects of E2 against $\mathrm{A} \beta$ involved the prevention of $\mathrm{Bax} / \mathrm{Bcl}-2$ ratio up-regulation, subsequent cytochrome $\mathrm{c}$ mitochondrial release and caspase 3 activation [92]. They could also be associated with an increased expression of the insulin-degrading enzyme involved in $A \beta$ clearance [82] as well as enhanced $A \beta$ proteases and somatostatinergic systems [93]. Intriguingly, E2 actions occurred independently of classical estrogen receptor mechanisms. Of note, previous studies indicate that brain E2 deficiency accelerated A $\beta$ deposition in APP23 mice (overexpressing the human APP751 with familial Swedish AD double mutation KM670/671NL) [52]. This report highlighted the potential protective role of local E2 levels in the female brain as compared to chronic ovarian hormone deprivation.

\subsection{Tau Pathology}

Research on tau protein revealed that it undergoes several changes in the AD brain, mainly hyperphosphorylation, truncation, aggregation, seeding and spreading. Tau oligomers, fibrils and aggregates constitutive of NFTs exert neurotoxicity in AD. Hyperphosphorylated tau (PHF-tau) is well-described and closely connected with neurodegeneration and cognitive dysfunction in AD (for review [94]). In contrast to $A \beta$, the relationship between tau and steroids is still in its infancy.

We previously demonstrated that hyperphosphorylated tau levels (recognized by AT8 antibody) were negatively correlated with DHEAS concentrations in the hypothalamus of aged AD patients as compared with nondemented ones [39]. In patients with FTD, low amounts of PROG in the serum significantly correlated with low disease severity [95], but the link with brain PROG was lacking. Interestingly, some studies reported the effects of neuroactive steroids on physiological and pathological tau levels. For instance, PROG treatment significantly decreased total tau in human neuroblastoma SK-N-MC cell line [95]. In ovariectomized 3xTg-AD mice, both cyclic and continuous 
PROG treatment (25.0 pellet s.c. for three months) significantly attenuated hyperphosphorylated tau levels (recognized by AT8 antibody) in the hippocampus and cortex, as compared to control mice [81,91]. The way in which PROG exerts its protective effect on tau hyperphosphorylation is unknown.

Testosterone treatment (10 $\mathrm{mg}$ pellet s.c. continuous delivery for two months) reduced tau hyperphosphorylation (AT8) in the CA1 hippocampus gonadectomized male 3xTg-AD mice to levels lower than observed in controls, independently of androgen receptor activation [89]. The influence of $\mathrm{E} 2$ on AD-like tau pathology has been described, but discrepancies have been noted depending on the in vitro and in vivo models. E2 treatment sustained tau hyperphosphorylation induced by protein kinase A activation in human embryonic kidney HEK293 cells stably expressing tau441 [96]. Similarly, it enhanced tau phosphorylation on several epitopes (Ser396, Ser262 but not Ser202/Thr205 (AT8)) through adenosine monophosphate protein kinase activation human SH-SH5Y neuroblastoma cells [97]. In contrast, it attenuated tau hyperphosphorylation at multiple sites (S396/404, Thr231, Thr205, S199/202) induced by transient GSK3 $\beta$ overexpression in mouse N2A neuroblastoma cells [98]. In ovariectomized 3xTg-AD, E2 individual treatment was ineffective on tau phosphorylation whereas combined E2 and PROG treatment reduced phosphotau (AT8) levels [81]. Whether sex steroids regulate other pathological forms of tau such as tau oligomers deserves further investigation. Recently, the impact of sex on tau pathology was mentioned in the P301L model of FTD, with female mice displaying significantly higher total tau and phosphotau levels (AT8 and AT100 (ptau-T212/S214) positive neurons) in the cerebral cortex and hippocampus than males [99]. It is likely that the severity of sex-related tauopathy depends partly on local sex steroid levels, but this remains to be shown. One earlier exploratory study in women with FTD aged 70 year-old indicated a high correlation between estrogen use and the development of FTD, suggesting that estrogen replacement therapy may be contraindicated in women with early FTD symptoms [100].

\subsection{Mitochondrial Impairment}

Mitochondria are highly dynamic organelles essential for the bioenergetic state of the cell. Mitochondrial dysfunction results in decreased energy production, weakened respiratory function, altered calcium homeostasis, oxidative stress or neuroinflammation that leads to neuronal death. Mitochondrial defects are features of both sporadic and familial AD. It is known that $\mathrm{A} \beta$ and hyperphosphorylated tau negatively impact mitochondrial function. Alternatively, mitochondrial dysfunction can generate $A \beta$ accumulation or be independent of $A \beta$ (for review [101]).

Consequences of mitochondrial dysfunction, particularly oxidative stress, can influence brain steroid levels and steroidogenic pathways and therefore may have an implication in AD. Treatment with ferrous sulfate-catalyzed oxidative neuronal damage caused a significant increase in DHEA levels in the hippocampus and frontal cortex of AD patients [102]. The authors indicated that DHEA production may come from an oxygenated metabolite of PREG or cholesterol. It was unclear if this endogenous mechanism was able to rescue neurons from death. Low DHEAS in aged rat brain was found to be associated with reduced antioxidant glutathione [103]. This result may have implication in AD pathology since reduction in brain glutathione content is a prominent feature of the disease [104]. Upregulation of glutathione or DHEAS levels is a potential strategy to consider for slowing down AD progression [105]. In addition, sex steroid loss and sex differences are linked to the mitochondrial dysfunction. Impaired mitochondrial function was found in female 3xTg-AD brains at a late stage (nine months and onwards) of AD-like disease while at an early stage (around one month) in males [106]. Furthermore, chronic ovarian hormone deprivation by ovariectomy in 3xTg-AD mice exacerbated brain bioenergetics deficits [107].

Multiple approaches have been undertaken to target mitochondrial abnormalities for developing neuroprotective strategies. Regarding neurosteroids, they have been shown to display varied antioxidant effects against oxidative stress-induced cell death caused by A $\beta$ (Table 1). 
Table 1. Protective effects of neuroactive steroids on $A \beta$-induced mitochondrial impairment.

\begin{tabular}{|c|c|c|}
\hline DHEA & Allopregnanolone & E2 \\
\hline $\begin{array}{l}\text { In vitro } \\
\text { Forebrain mitochondria from male } \\
\text { Swiss mouse }+\mathrm{A} \beta_{1-42}(4 \mu \mathrm{M}) \text { or } \\
\mathrm{A} \beta_{25-35}(50 \mu \mathrm{M}) \text { for } 20 \mathrm{~min} \\
\\
\text { DHEA }(3,10 \text { or } 30 \mu \mathrm{M}, 20 \mathrm{~min}) \\
\downarrow \text { mitochondrial respiration } \\
\text { dysfunction through } \sigma 1 \text { receptor } \\
\text { mechanism } \\
\downarrow \text { increased ROS production } \\
{[108]}\end{array}$ & $\begin{array}{l}\text { In vitro } \\
\mathrm{PC} 12 \text { cells }+ \text { aggregated } \mathrm{A} \beta_{25-35} \\
(20 \mu \mathrm{M}, 24 \mathrm{~h}) \\
\text { Allopregnanolone pretreatment } \\
(10 \mu \mathrm{M}, 2 \mathrm{~h}) \\
\downarrow \text { ROS generation } \\
\downarrow \text { SOD activity } \\
{[109]}\end{array}$ & $\begin{array}{l}\text { In vitro } \\
\text { Choroid plexus explants or cell line } \\
\mathrm{Z} 310+\mathrm{A} \beta_{1-42}(0.66 \mu \mathrm{M}, 24 \mathrm{~h}) \\
\text { E2 pretreatment }(1 \mu \mathrm{M}, 8-12 \mathrm{~h}) \downarrow \\
\text { ROS production, } \downarrow \mathrm{A} \beta \text { uptake } \\
\text { [110] } \\
\text { In vivo } \\
\text { Ovariectomized } 3 \times \mathrm{Tg} \text {-AD mice } \\
\text { E2 treatment }(0.25 \text { mg continuous } \\
90 \text {-day pellet) prevented in isolated } \\
\text { forebrain mitochondria: } \\
\downarrow \text { respiration, } \downarrow \text { energy deficits } \\
\downarrow \mathrm{A} \beta \text { load, } \downarrow \text { lipid peroxidation } \\
{[107]}\end{array}$ \\
\hline
\end{tabular}

$\downarrow$ : decrease $\uparrow:$ increase vs. $A \beta$ condition.

DHEA treatment of isolated mouse brain mitochondria attenuated the decreased mitochondrial respiration and increase in reactive oxygen species (ROS) production induced by A $\beta$ peptide [108]. Allopregnanolone significantly diminished the intracellular production of ROS, enhanced superoxide dismutase (SOD) activity involved in A $\beta$-induced PC12 cell death [109]. Notably, we previously demonstrated the antioxidant neuroprotective effects of the synthetic enantiomers of PREGS and DHEAS, which prevented $\mathrm{a} \beta_{25-35}$-induced lipid peroxidation in the mouse hippocampus [78]. Whether PROG regulates AD-induced mitochondrial dysfunction is still unknown, but its benefits in normal brain mitochondria include enhancing functional efficiency and increased metabolic rates [111]. The effects of PREG, DHEA and their sulfated derivatives on mitochondrial deficits are currently lacking.

A complex relationship exists between sex steroids and mitochondrial function that depends on sex, aging or disease (for review [112]). In $\mathrm{AD}$, the role of $\mathrm{E} 2$ on the maintenance and function of mitochondria is ambiguous [113]. A selection of studies demonstrated the neuroprotective effects of E2 against AD-related mitochondrial injury. E2 pretreatment $(10 \mathrm{nM}, 24 \mathrm{~h})$ protected against the heavy metal (cobalt and mercury) induced oxidative stress (loss of glutathione) and the increase in $\mathrm{A} \beta_{1-40}$ secretion in SH-SY5Y neuroblastoma cells [114]. E2 pretreatment (100 $\mathrm{nM}$ and $1 \mu \mathrm{M}, 2 \mathrm{~h})$ preserved mitochondrial membrane potential and intracellular $\mathrm{Ca} 2+$ homeostasis, attenuated ATP depletion, and reduced mitochondrial calcium overload induced by $\mathrm{H}_{2} \mathrm{O}_{2}(150 \mu \mathrm{M})$ toxicity in human neuroblastoma SH-N-SY cells [115]. E2 pretreatment protected against $A \beta_{1-42}$-induced generation of ROS in choroid plexus explants and cultured choroid plexus epithelial cells through the E2 receptor-dependent internalization of reduction of $A \beta$ uptake [110] (Table 1). Notably, E2 exacerbation of oxidative stress-induced-cell death was recently unveiled in C6 glial cells and N27 neuronal cells and explained by the time window, i.e., deleterious steroid post-treatment vs. beneficial steroid pretreatment [116]. E2 treatment of ovariectomized 3xTg-AD mice prevented the decrease in mitochondrial respiration, increase in oxidative stress and the subsequent $A \beta$-accumulation in brain induced by ovariectomy [107] (Table 1 ). Of interest are the few studies attesting for a sex-steroid difference in oxidative stress markers in AD patients. For instance, the higher activities of superoxide dismutase and glutathione peroxidase in postmortem AD brain compared to controls were further upregulated in women than men $[117,118]$.

\subsection{Neuroinflammation}

Neuroinflammation was historically considered as a secondary event in neurodegenerative diseases. Accumulating evidence now suggests that it is a key mechanism in AD initiation and 
progression. Abnormalities of $A \beta$ and tau cause activation of microglia and astrocytes, and trigger the innate immune system by releasing proinflammatory mediators (for reviews [119,120]). Recent studies have revealed different types of pathological microglia associated with $\mathrm{AD}$ and key regulators of the microglia pathogenicity, such as the triggering receptor expressed on myeloid cells 2 [121,122]. Therefore, glial activation with associated inflammatory mediators and regulators are important targets for therapeutic approaches in $\mathrm{AD}$ research.

Few studies have addressed the role of neurosteroids in preventing neuroinflammation in AD with an impact on $A \beta$-induced increase in cytokine secretion and microglial activation. PROG blocked $\mathrm{A} \beta_{25-35}$-mediated upregulation of TNF $\alpha$ and interleukin-1 (IL-1) and concomitantly increased cell survival in rat hippocampus [43]. PROG suppressed inflammatory responses induced by oligomeric $\mathrm{A} \beta_{1-42}$ in primary astrocyte cultures, including IL- $\beta$ and TNF- $\alpha$ production. The reduction of endoplasmic reticulum stress markers (PERK/elF $2 \alpha$ ) triggered by A $\beta$ was believed to be part of the PROG anti-inflammatory action [123].

Strong interactions between sex steroids and chronic inflammation were evidenced in AD (for review [124]). Physiological concentrations of E2 and testosterone displayed anti-inflammatory activities in several AD models (Table 2). In APP23 transgenic mice (overexpressing human APP751 with the familial Swedish AD double mutation), ovariectomy led to more $\mathrm{A} \beta$ plaques associated with reactive microglia that parallel disease progression. Chronic E2 administration delayed this process by directly acting on resident microglia helping them to remove to $A \beta$ [125]. In a primary culture of microglia derived from human cortex, E2 treatment enhanced uptake of $A \beta$ [126]. The E2 anti-inflammatory effect was likely to be mediated via the decrease of the A $\beta$-induced NF- $\mathrm{kB}$ activation, which is critical for the induction of inflammatory response genes in activated BV-2 microglial cells [125,127]. Testosterone and its $5 \alpha$-reduced metabolite $5 \alpha$-dihydrotestosterone promote microglia to phagocytose and clear $A \beta$ and inhibit proinflammatory cytokine expression in $A \beta$-activated murine microglia cell cultures (Table 2). Androgen administration also reduced $A \beta_{1-42}$-induced IL- $\beta$ expression and neuronal death in the murine hippocampus. These anti-inflammatory effects were mediated by the suppression of $\mathrm{a} \beta$-induced NF- $\mathrm{kB}$ and $\mathrm{p} 38$ mitogen-activated protein kinase activation [128]. In addition, $5 \alpha$-dihydrotestosterone promoted $A \beta$ uptake by microglia through increasing formyl peptide receptor 2 (FPR2) and enhanced $A \beta$ clearance by increasing the levels of the $A \beta$ degrading enzyme endothelin-converting enzyme 1c (Table 2) [128]. Thus, the anti-inflammatory activities of E2 and testosterone contribute to their protective effects on $A \beta$-activated microglia-induced neurotoxicity, independently of their respective classical receptors. Direct regulation of resident microglia by steroids inhibiting chronic inflammation associated with AD may be a valuable therapeutic strategy of AD.

Only limited studies have focused on tau pathology and neuroinflammation (for review [129]). Tau-mediated neuroinflammation and disease was evidenced in AD patients and models of pure tauopathy. For instance, positron emission tomography (PET) analysis of AD patient brains showed a direct positive correlation between tau aggregation and microglial activation in the parahippocampus at the early stage of the disease [130]. Activated microglia/infiltrating macrophages as well as induction and overproduction of inflammatory mediators (IL-1 $\beta$ and cyclooxygenase-2) were detected in the hippocampus and cortex of P301S transgenic mice and in the brain a patient with FTD associated with P301S mutation [131,132]. In fact, distinct microglial responses were observed depending on the type of tau pathology, tau phosphorylation state and it is even believed that reducing microglia number does not change tau pathological lesions [133-135]. In this context, the role of neuroactive steroids in tau-mediated neuroinflammation awaits further experimentation.

\subsection{Neurogenesis, Synaptic Failure and Memory Loss}

Neuronal loss in AD leads to progressive brain atrophy. Neurogenesis, which allows the endogenous formation of newly born neurons in the adult brain, is known to be less efficient during aging and in neurodegenerative diseases. Reduced neurogenesis in AD is associated with the lack of maturation and functional integration of newborn neurons in late stages of the disease [136]. Therefore, 
stimulating endogenous neurogenesis could be a therapeutic target for early intervention in AD. The neurosteroid modulation may have possible benefits on the course of the disease by increasing survival of adult-born neurons contributing to memory improvement.

Table 2. Neuroactive steroid protective effects on $\mathrm{A} \beta$-induced neuroinflammation.

\begin{tabular}{|c|c|c|}
\hline Steroid Treatment & $\begin{array}{l}\text { Models of } A \beta \text {-induced } \\
\text { Inflammation }\end{array}$ & $\begin{array}{l}\text { Inflammatory Response against } \\
\text { A } \beta \text { Neurotoxicity }\end{array}$ \\
\hline $\begin{array}{l}\text { PROG } \\
\text { Pretreatment } 4,8 \text { or } 16 \mathrm{mg} / \mathrm{kg} \text {, i.p. } \\
\text { daily, for } 7 \text { and } 12 \text { days after } \mathrm{A} \beta \\
\text { injection }\end{array}$ & $\begin{array}{l}\text { In vivo } \\
\text { Male rats + aggregated } \mathrm{A} \beta_{25-35} \\
5 \mu \mathrm{M} \text { in the hippocampal } \\
\text { CA1 region }\end{array}$ & $\begin{array}{l}\downarrow \text { the upregulation of TNF } \alpha \text { and } \\
\text { IL- } 1 \beta \text { induced by A } \beta[43] \\
\downarrow \text { endoplasmic reticulum stress } \\
\text { markers PERK/elF } 2 \alpha\end{array}$ \\
\hline $\begin{array}{l}\text { E2 pretreatment } \\
\text { pellets } 0.01 \mathrm{mg} \text { s.c. daily, from } 5 \text { to } \\
10-14 \text { months of age }\end{array}$ & $\begin{array}{l}\text { In vivo } \\
\text { Ovariectomized APP23 mice, } \\
10-14 \text { months of age } \\
\text { (early stage of disease) }\end{array}$ & $\begin{array}{l}\downarrow \text { Mac- } 1 \text { positive inflammatory } \\
\text { plaques } \\
\uparrow \text { microglia clearance of } A \beta \\
{[125]}\end{array}$ \\
\hline $\begin{array}{l}\text { E2 pretreatment } \\
100 \mathrm{nM}, 48 \mathrm{~h} \\
\text { E2 pretreatment }\end{array}$ & $\begin{array}{l}\text { In vitro } \\
\text { Human cortical microglia } \\
+ \text { fluorescein- } \mathrm{A} \beta_{1-42} 100 \mathrm{nM}\end{array}$ & $\begin{array}{l}\uparrow \text { microglia uptake of } A \beta, \text { through } \\
\text { non-classical estrogen receptor } \\
\text { [126] }\end{array}$ \\
\hline & $\begin{array}{l}\text { Microglial BV-2 cell } \\
+ \text { aggregated } A \beta_{1-42} 1 \mu \mathrm{M}\end{array}$ & $\begin{array}{l}\downarrow A \beta \text {-induced NF-кB } \\
{[125,127]}\end{array}$ \\
\hline $\begin{array}{l}\text { Pretreatment } \\
\text { Testosterone } 100 \mathrm{nM} \\
\text { Dihydrotestosterone } 10 \mathrm{nM}\end{array}$ & $\begin{array}{l}\text { Murine microglia N9 cell line } \\
+ \text { aggregated } A \beta_{1-42}(2 \mu \mathrm{M}) \text { for } \\
30 \text { min }\end{array}$ & $\begin{array}{l}\downarrow A \beta \text {-induced proinflammatory } \\
\text { cytokine IL- } 1 \beta \text { via suppression of } \\
\text { NF- } \mathrm{B} \text { and p38 activation by A } \beta \\
{[128]}\end{array}$ \\
\hline Pretreatment & Male C57BL/6 mice + aggregated & \\
\hline $\begin{array}{l}\text { Testosterone } 200 \mu \mathrm{g} \\
\text { Dihydrotestosterone } 100 \mu \mathrm{g}\end{array}$ & $A \beta_{1-42}(1 \mu \mathrm{M})$ into the $\mathrm{CA} 1$ region & $\begin{array}{l}\downarrow \text { A } \beta \text {-induced proinflammatory } \\
\text { cytokine IL-1 } \beta[128]\end{array}$ \\
\hline $\begin{array}{l}\text { s.c. every day for } 2 \text { weeks } \\
\text { Pretreatment } \\
\text { Dihydrotestosterone } 0.5 \text { and } 1 \mathrm{nM} \\
\text { for } 6 \mathrm{~h}\end{array}$ & $\begin{array}{l}\text { Murine microglia N9 cell line }+ \\
\text { aggregated } A \beta_{1-42} \\
1 \mu \mathrm{M} \text { for } 1 \mathrm{~h} \text { or } 24 \mathrm{~h}\end{array}$ & $\begin{array}{l}\uparrow \text { microglia } \mathrm{A} \beta \text { uptake through } \\
\text { upregulating FPR } 2 \\
\uparrow \text { microglia clearance of } \mathrm{A} \beta \\
\text { through upregulating ECE- } 1 \mathrm{c} \text { [128] }\end{array}$ \\
\hline
\end{tabular}

$\downarrow$ decrease, $\uparrow$ increase vs. $\mathrm{A} \beta$ condition.

PREGS significantly reduced the impairment of neurite growth as well as survival and maturation of hippocampal dentate gyrus newborn neurons of APPswe/PS1dE9 mice [137]. Several studies in the laboratory of Brinton D. demonstrated the efficacy of allopregnanolone in promoting neurogenesis in the hippocampal subgranular zone of 3xTg-AD mice [86]. The regenerative action of allopregnanolone involved $\mathrm{GABA}_{\mathrm{A}}-\mathrm{R}$ activation inducing chloride ion efflux from neural progenitor and upregulation of cell cycle genes that promote mitosis and repress cell division [138]. PREGS and DHEAS neurotrophic effects were observed in cultured rat neuroblastoma cells by the significant reduction of $A \beta_{25}-35$-induced decrease of neurite growth [78].

Sex steroids are also important players in regulating adult hippocampal neurogenesis. There is ample evidence that E2 and testosterone enhanced the hippocampal dentate gyrus neuronal renewal in young adult female and male rodents, resulting in increased memory function (for reviews $[139,140]$ ). By contrast, literature highlighting their impact on neurogenesis in AD models is poor. One study indicated that chronic E2 administration significantly increased hippocampal neurogenesis in ovariectomized mice injected with $A \beta_{1-42}$ into the brain. This E2 protective effect occurring during the early, not late, stage of the $A \beta$ pathological process, alleviated memory loss [141]. The effects of androgens on neurogenesis in AD models are yet to be discovered. 
Synaptic impairment in the neocortex and hippocampus is an early pathological feature of AD that correlates strongly with cognitive decline. Multiple studies support that pathological A $\beta$ and tau affect the integrity of synaptic function individually and in interaction with several complex mechanisms that lead to impaired synaptic plasticity, neurotransmitter receptor dysfunction and memory loss (for reviews [3,142]). Thus, preventing synaptic dysfunction may be an attractive approach to delay $\mathrm{AD}$ progression and symptoms.

Under physiological conditions, neuroactive steroids play a significant role in the integrity of synapses and the modulation of synaptic plasticity underlying learning and memory. PREGS is a well-known modulator of glutamatergic excitatory synaptic transmission and plasticity. It sustains presynaptic glutamate release, potentiates glutamatergic post-synaptic N-methyl-D-aspartate receptor (NMDA-R) function, induces its trafficking and enhances long-term potentiation $[143,144]$. Allopregnanolone is a potent allosteric modulator of $\mathrm{GABA}_{\mathrm{A}}$ receptor activity thereby exerts control over neuronal excitability. Recently, it was shown to increase mature excitatory synapse dendritic spines of cultured mature hippocampal neurons [145]. E2 regulated excitatory synaptic transmission in hippocampal neurons via estrogen receptor activation and by altering synaptic distribution of NMDA-Rs in prefrontal cortex $[146,147]$. Testosterone also enhanced genesis of spines through androgen receptor activation $[148,149]$.

Surprisingly, the modulation of synaptic function and plasticity by steroids in AD is almost unexplored. One report highlighted the beneficial effects of E2 on early-A $\beta_{25-35}$-induced synaptic dysfunction in organotypic hippocampal cultures [150]. Testosterone improved the oligomeric A $\beta$-induced presynaptic failure in primary cultures of hippocampal neurons [151]. Sex impact on postsynaptic protein levels was shown in P301L mice, and a more severe synaptopathy observed in females than males [99]. The potential protective effects of neuroactive (neuro)steroids on synaptic dysfunction associated with $A \beta$ and tau pathology needs to be widely explored.

Tremendous efforts have been devoted to characterizing the progressive impairment in learning and memory in the course of AD. Early stages of AD are marked by salient deficits in episodic and working memory as well as novelty processing impairment $[4,152]$. Although animal AD models do not fully recapitulate human AD cognitive deficits, they are a very useful tool for assessing memory functioning and pharmacological intervention in behavioral tasks [153].

Evidence demonstrates that neuroactive steroids differentially regulate learning and memory performance in rodents. The memory deficits induced by $a \beta_{25-35}$ acute central administration in young adult male mice were attenuated by PREGS and DHEAS in the spontaneous alternation, passive avoidance or Morris water maze tests $[78,154]$ (Table 3). The PREGS and DHEAS protective effects against $A \beta_{25-35}$-induced amnesia involved the activation of sigma1 and $\alpha 7$ nicotinic acetylcholine receptors $[154,155]$. Interestingly, the synthetic enantiomeric analogues of PREGS and DHEAS also behaved as antiamnestic molecules against $A \beta_{25-35}$ in young adult mice [78]. Acute PROG treatment was devoid of activity per se in this model but prevented the antiamnesic effect of natural PREGS and DHEA through sigma1 receptor modulation [154]. By contrast, chronic PROG administration restored the spatial/hippocampal memory deficits in mid-age mutant female APPswePSEN1 $\Delta \mathrm{e} 9$ mice tested in the object placement and water maze tasks. This improvement involved increased PROG metabolism towards allopregnanolone in the cerebral cortex but not in the hippocampus of transgenic mice [156]. Curiously, chronic allopregnanolone in the same APPSwe/PS1 mouse model caused memory impairment in males, not females, with an accelerated disease progression [84,85]. In mid-aged 3xTg-AD mice, not aged, allopregnanolone single injection remarkably restored hippocampal associative learning that depended on the survival of newly generated neurons in the dentate gyrus [157]. The underlying mechanisms of allopregnanolone age and sex-dependent action on AD-related memory impairment need further research. 
Table 3. Effects of neuroactive steroids on impaired neurogenesis and memory in AD models.

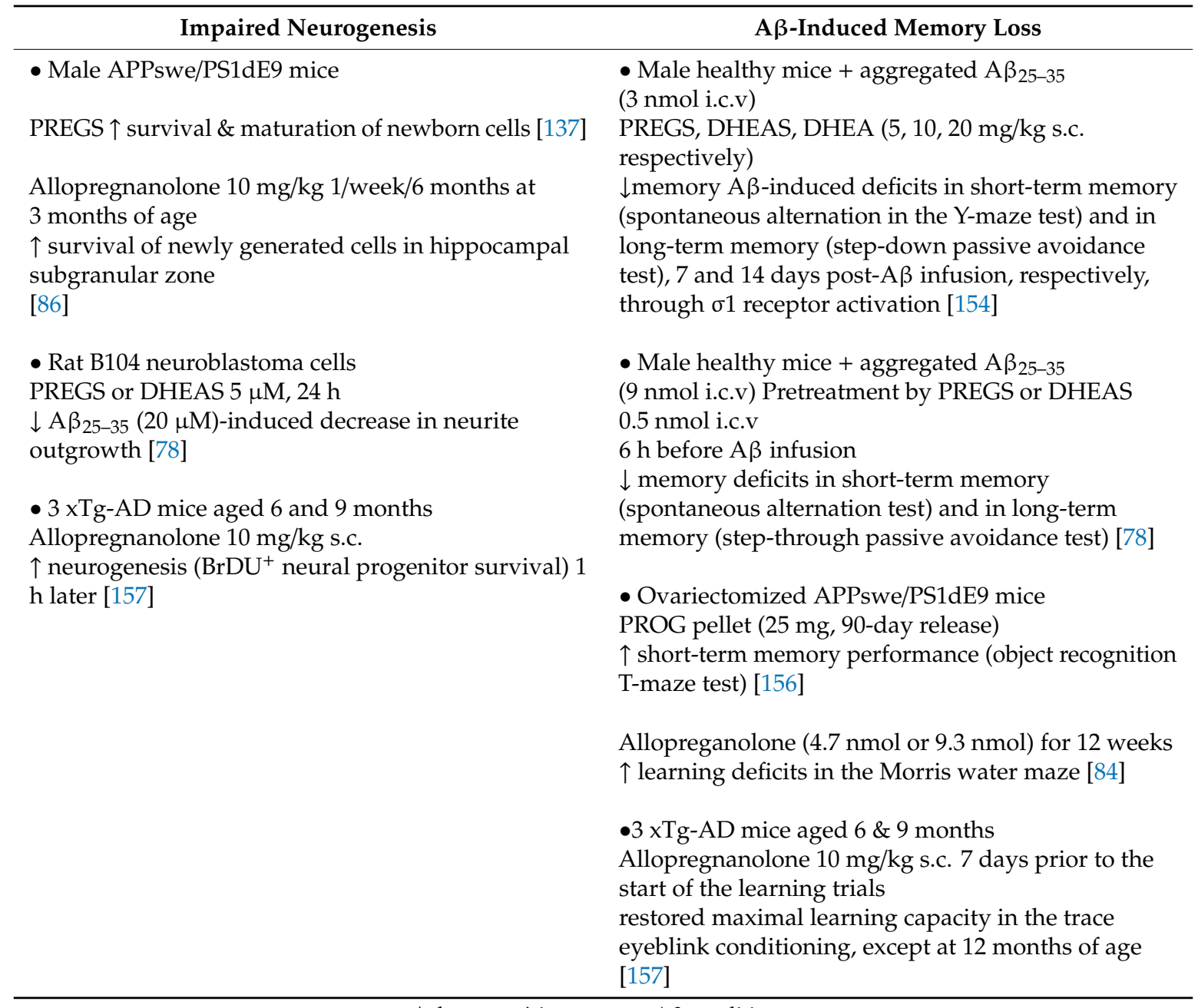

$\downarrow$ decrease, $\uparrow$ increase vs. $\mathrm{A} \beta$ condition.

The influence of sex steroids on memory function in humans and rodents has been comprehensively reviewed in literature. However, a great diversity of outcomes has been obtained (i.e., improvement, decrease or no effect) depending on the disease stage, subject gender, study design, modes of delivery, type of memory evaluated and steroid dosage, among others. This is true for androgenic neuroactive steroids DHEA, DHEAS, testosterone and for estrogen (for reviews [158-160]).

\section{Modulation of Endogenous Neuroactive Steroid Production for Protection in AD}

Restoration of steroid homeostasis could be achieved by the supplementation of neuroactive steroids with a proper dosing and treatment regimen. Nowadays, an innovative strategy that is more and more attractive is to restore altered endogenous levels of protective steroids by promoting neurosteroidogenesis. In this context, targeting the $18 \mathrm{kDa}$ translocator protein (TSPO) is becoming a valuable strategy [161]. TSPO is a high-affinity cholesterol-binding protein involved in the intramitochondrial cholesterol transport and steroid biosynthesis [162]. It is predominantly expressed in steroid-synthesizing organs including brain, and TSPO ligand treatment increases concentrations of several steroids. For instance, the pharmacodynamic study recently conducted by our group revealed that TSPO activation by etifoxine stimulated steroidogenesis in male rat brain, preferentially towards the synthesis of PREG, PROG and allopregnanolone [163], suggesting a differential regulation of neurosteroid production by this TSPO agonist. 
Moreover, TSPO is upregulated in reactive glial cells during CNS pathologies, including $\mathrm{AD}[164,165]$. It is involved in the control of many fundamental functions including mitochondrial respiration and permeability, energy metabolism, cell proliferation and differentiation. Several TSPO ligands have proven their efficacy as neuroprotective, anti-inflammatory and regenerating molecules in experimental AD models [166]. The TSPO ligand Ro5-4864 (4'-chlorodiazepam) was neuroprotective against $A \beta_{1-40}$-induced neurotoxicity in SH-5YSY neuroblastoma cells. It reduced the $A \beta$-induced apoptotic Bax upregulation and downregulation of survivin, a member of the inhibitor of apoptosis protein family [167]. In human SH-SY5Y neuroblastoma cells transfected with wild-type APP, TSPO ligand treatment $(10 \mathrm{nM}, 24 \mathrm{~h})$ including two TSPO ligands of reference XDB173 and SSR-180,575 and two new imidazoquinazolinone compounds exerted neuroprotective effects. All compounds were able to improve mitochondrial respiration, decrease ROS and A $\beta$ level while enhancing PREG synthesis [168]. In SH-SY5Y cells expressing the pathological tau-P301L and therefore abnormal tau hyperphosphorylation, a treatment with the same TSPO ligands (10-100 nM, $24 \mathrm{~h}$ ) increased mitochondrial bioenergetics (ATP levels and mitochondrial membrane potential) [169]. They also improved the production of PREG at $20 \mu \mathrm{M}$ at $2 \mathrm{~h}$ [169]. Furthermore, TSPO ligand efficacy was proven in in vivo AD models. Ro5-4864 (3 mg/kg i.p. once weekly for three months) in young and aged male 3xTg-AD mice improved memory loss (performance in the spontaneous alternation test) while attenuating hippocampal $\mathrm{A} \beta$ accumulation and gliosis [170]. Steroid synthesis occurred in the brain following Ro5-4864 injection ( $3 \mathrm{mg} / \mathrm{kg}$ i.p. once weekly beginning two weeks after surgery and continuing for four weeks) in gonadectomized 3xTg-AD mice. In young adults, PROG and testosterone levels significantly decreased in the brain whereas those of PREG allopregnanolone were not significantly affected [170]. In aged 3xTg-AD mice, Ro5-4864 did not significantly alter brain levels of testosterone; however brain levels of PROG and allopregnanolone decreased and brain PREG were unchanged [170]. PK11195 treatment (3 mg/kg i.p. once weekly for five weeks) in aged female $3 x T g-A D$ mice improved memory (performance in the spontaneous alternation test) while reducing both soluble and aggregated $A \beta[171]$.

\section{Concluding Remarks}

Protective strategies that increase neural functioning as well as attenuating multiple aspects of AD-related neuropathology are more than welcome for treating AD. Preclinical evidence indicates that neurosteroids and sex steroids can promote neuronal survival, neurogenesis and memory function, by limiting apoptosis, oxidative stress, mitochondrial failure and microglial activation. In some cases, steroid beneficial effects depend on sex and stage of the neuropathology process. TSPO ligands also confer protection against AD-related pathology and they are worthy of constant research in the context of AD treatment. Studies still need improvement by answering questions with regard to the true model with AD fully represented, the therapeutic time window of intervention as well as solutions for reproducing molecule efficacy and safety. In addition, our knowledge of neurosteroids, steroid enzymes and metabolism in the AD brain and CSF during the course of the disease is far from complete, and larger studies using standardized validated protocols are required. Revitalizing research on steroids in AD with novel concepts close to human condition may help to obtain better and successfully translated benefits in patients with AD. So far, the translation of basic research on steroids in AD has not been fruitful. Gaps are yet to be filled regarding appropriate steroid formulation, dosing and regimen, alone or in combination, administration routes and bioavailability. Also, because of sex differences in $\mathrm{AD}$ pathology and outcomes, there is an urgent need for new sex-specific, even personalized, steroid-based therapies. As the AD pathogenesis starts decades before symptoms appear, the question remains as to the earliest possible ethical intervention.

Author Contributions: The author confirms she is the sole contributor of this work and approved it for publication. The author has read and agreed to the published version of the manuscript.

Funding: The publication fees of this review were covered by Inserm funds. 
Conflicts of Interest: The author declares that the research was conducted in the absence of any commercial or financial relationships that could be construed as a potential conflict of interest.

\section{Abbreviations}

$\mathrm{AD}$

ApoE

APP

$\mathrm{A} \beta$

CNS

CSF

DHEA

DHEAS

E2

FTD

GABAA-R

GC-MS

IL-1 $\beta$

mTOR

NF-кB

NTFs

P450scc

PI3K

PREG

PREGS

PROG

PS1

ROS

TNF $\alpha$

TSPO

yrs.

$3 \times \mathrm{Tg}-\mathrm{AD}$

$3 \alpha, 5 \alpha-\mathrm{THP}$

$3 \alpha-\mathrm{HSD}$

$3 \beta-\mathrm{HSD}$

$3 \beta-\mathrm{HST}$

$5 \alpha$-DHP

$17 \beta-H S D$

\author{
Alzheimer's disease \\ apolipoprotein \\ amyloid precursor protein \\ Amyloid- $\beta$ \\ central nervous system \\ cerebrospinal fluid \\ dehydroepiandrosterone \\ dehydroepiandrosterone sulfate \\ $17 \beta$-estradiol \\ frontotemporal dementia \\ $\gamma$-aminobutyric acid type A receptor \\ gas chromatography-mass spectrometry \\ interleukin-1 $\beta$ \\ mechanistic target of rapamycin \\ nuclear factor-kappa B \\ neurofibrillary tangles \\ P450side chain cleavage \\ phosphoinositide 3-kinase \\ pregnenolone \\ pregnenolone sulfate \\ progesterone \\ presenilin-1 \\ reactive oxygen species \\ tumor necrosis factor alpha \\ $18 \mathrm{kDa}$ translocator protein \\ years \\ triple transgenic mouse bearing the human APPSWE, TauP301L, and PS1M146V \\ genes linked to AD and FTD \\ $3 \alpha, 5 \alpha$-tetrahydroprogesterone, allopregnanolone \\ $3 \alpha$-hydrosteroid dehydrogenase \\ $3 \alpha$-hydroxysteroid dehydrogenase-D5 $\Delta 5 \rightarrow \Delta 4 \mathrm{D} 4$ isomerase \\ $3 \beta$-hydroxysteroid sulfotransferase \\ $5 \alpha$-dihydroprogesterone \\ $17 \alpha$-hydroxysteroid dehydrogenase
}

\section{References}

1. Lane, C.A.; Hardy, J.; Schott, J.M. Alzheimer's disease. Eur. J. Neurol. 2018, 25, 59-70. [CrossRef] [PubMed]

2. Ono, K. Alzheimer's disease as oligomeropathy. Neurochem. Int. 2018, 119, 57-70. [CrossRef] [PubMed]

3. Li, S.; Selkoe, D.J. A mechanistic hypothesis for the impairment of synaptic plasticity by soluble A $\beta$ oligomers from Alzheimer brain. J. Neurochem. 2020. [CrossRef] [PubMed]

4. Bastin, C.; Delhaye, E.; Moulin, C.; Barbeau, E.J. Novelty processing and memory impairment in Alzheimer's disease: A review. Neurosci. Biobehav. Rev. 2019, 100, 237-249. [CrossRef] [PubMed]

5. Galts, C.P.C.; Bettio, L.E.B.; Jewett, D.C.; Yang, C.C.; Brocardo, P.S.; Rodrigues, A.S.; Thacker, J.S.; Gil-Mohapel, J. Depression in neurodegenerative diseases: Common mechanisms and current treatment options. Neurosci. Biobehav. R 2019, 102, 56-84. [CrossRef]

6. Rajan, K.B.; Wilson, R.S.; Weuve, J.; Barnes, L.L.; Evans, D.A. Cognitive impairment 18 years before clinical diagnosis of Alzheimer disease dementia. Neurology 2015, 85, 898-904. [CrossRef] 
7. Heffernan, A.L.; Chidgey, C.; Peng, P.; Masters, C.L.; Roberts, B.R. The Neurobiology and Age-Related Prevalence of the epsilon4 Allele of Apolipoprotein E in Alzheimer's Disease Cohorts. J. Mol. Neurosci. 2016, 60, 316-324. [CrossRef]

8. Riedel, B.C.; Thompson, P.M.; Brinton, R.D. Age, APOE and sex: Triad of risk of Alzheimer's disease. J. Steroid Biochem. Mol. Biol. 2016, 160, 134-147. [CrossRef]

9. Brinton, R.D. Neurosteroids as regenerative agents in the brain: Therapeutic implications. Nat. Rev. Endocrinol. 2013, 9, 241-250. [CrossRef]

10. Melcangi, R.C.; Giatti, S.; Garcia-Segura, L.M. Levels and actions of neuroactive steroids in the nervous system under physiological and pathological conditions: Sex-specific features. Neurosci. Biobehav. Rev. 2016, 67, 25-40. [CrossRef]

11. Blanco, M.J.; La, D.; Coughlin, Q.; Newman, C.A.; Griffin, A.M.; Harrison, B.L.; Salituro, F.G. Breakthroughs in neuroactive steroid drug discovery. Bioorg. Med. Chem. Lett. 2018, 28, 61-70. [CrossRef]

12. Hojo, Y.; Kawato, S. Neurosteroids in Adult Hippocampus of Male and Female Rodents: Biosynthesis and Actions of Sex Steroids. Front. Endocrinol. (Lausanne) 2018, 9, 183. [CrossRef]

13. Papadopoulos, V.; Miller, W.L. Role of mitochondria in steroidogenesis. Best Pract. Res. Clin. Endocrinol. Metab. 2012, 26, 771-790. [CrossRef]

14. Stoffel-Wagner, B. Neurosteroid metabolism in the human brain. Eur. J. Endocrinol. 2001, 145, 669-679. [CrossRef]

15. Yu, L.; Romero, D.G.; Gomez-Sanchez, C.E.; Gomez-Sanchez, E.P. Steroidogenic enzyme gene expression in the human brain. Mol. Cell Endocrinol. 2002, 190, 9-17. [CrossRef]

16. Le Goascogne, C.; Gouezou, M.; Robel, P.; Defaye, G.; Chambaz, E.; Waterman, M.R.; Baulieu, E.E. The cholesterol side-chain cleavage complex in human brain white matter. J. Neuroendocr. 1989, 1, 153-156. [CrossRef]

17. Steckelbroeck, S.; Watzka, M.; Reichelt, R.; Hans, V.H.; Stoffel-Wagner, B.; Heidrich, D.D.; Schramm, J.; Bidlingmaier, F.; Klingmuller, D. Characterization of the $5 \alpha$-reductase- $3 \alpha$-hydroxysteroid dehydrogenase complex in the human brain. J. Clin. Endocrinol. Metab. 2001, 86, 1324-1331.

18. Penning, T.M.; Burczynski, M.E.; Jez, J.M.; Hung, C.F.; Lin, H.K.; Ma, H.; Moore, M.; Palackal, N.; Ratnam, K. Human 3 alpha-hydroxysteroid dehydrogenase isoforms (AKR1C1-AKR1C4) of the aldo-keto reductase superfamily: Functional plasticity and tissue distribution reveals roles in the inactivation and formation of male and female sex hormones. Biochem. J. 2000, 351 Pt 1, 67-77.

19. Usami, N.; Yamamoto, T.; Shintani, S.; Ishikura, S.; Higaki, Y.; Katagiri, Y.; Hara, A. Substrate specificity of human 3(20) alpha-hydroxysteroid dehydrogenase for neurosteroids and its inhibition by benzodiazepines. Biol. Pharm. Bull. 2002, 25, 441-445. [CrossRef]

20. Higaki, Y.; Usami, N.; Shintani, S.; Ishikura, S.; El-Kabbani, O.; Hara, A. Selective and potent inhibitors of human 20 alpha-hydroxysteroid dehydrogenase (AKR1C1) that metabolizes neurosteroids derived from progesterone. Chem. Biol. Interact. 2003, 143-144, 503-513. [CrossRef]

21. Falany, C.N.; Rohn-Glowacki, K.J. SULT2B1: Unique properties and characteristics of a hydroxysteroid sulfotransferase family. Drug Metab. Rev. 2013, 45, 388-400. [CrossRef] [PubMed]

22. Shimizu, M.; Tamura, H. Identification and localization of two hydroxysteroid sulfotransferases in the human brain. J. Health Sci. 2002, 48, 467-472. [CrossRef]

23. Steckelbroeck, S.; Watzka, M.; Stoffel-Wagner, B.; Hans, V.H.; Redel, L.; Clusmann, H.; Elger, C.E.; Bidlingmaier, F.; Klingmuller, D. Expression of the 17 $\beta$-hydroxysteroid dehydrogenase type $5 \mathrm{mRNA}$ in the human brain. Mol. Cell Endocrinol. 2001, 171, 165-168. [CrossRef]

24. Steckelbroeck, S.; Stoffel-Wagner, B.; Reichelt, R.; Schramm, J.; Bidlingmaier, F.; Siekmann, L.; Klingmuller, D. Characterization of $17 \beta$-hydroxysteroid dehydrogenase activity in brain tissue: Testosterone formation in the human temporal lobe. J. Neuroendocr. 1999, 11, 457-464. [CrossRef]

25. Weill-Engerer, S.; David, J.-P.; Sazdovitch, V.; Liere, P.; Schumacher, M.; Delacourte, A.; Baulieu, E.; Akwa, Y. In vitro metabolism of dehydroepiandrosterone (DHEA) to $7 \alpha-\mathrm{OH}$-DHEA and $\Delta 5$-androstene-3 $\beta, 17 \beta$-diol in specific regions of the aging brain from Alzheimer's and nondemented patients. Brain Res. 2003, 969, 117-125. [CrossRef]

26. He, X.Y.; Dobkin, C.; Yang, S.Y. 17 $\beta$-Hydroxysteroid dehydrogenases and neurosteroid metabolism in the central nervous system. Mol. Cell Endocrinol. 2019, 489, 92-97. [CrossRef] [PubMed] 
27. Stoffel-Wagner, B.; Watzka, M.; Steckelbroeck, S.; Schwaab, R.; Schramm, J.; Bidlingmaier, F.; Klingmuller, D. Expression of CYP19 (aromatase) mRNA in the human temporal lobe. Biochem. Biophys. Res. Commun. 1998, 244, 768-771. [CrossRef]

28. Sasano, H.; Takashashi, K.; Satoh, F.; Nagura, H.; Harada, N. Aromatase in the human central nervous system. Clin. Endocrinol. (Oxf.) 1998, 48, 325-329. [CrossRef]

29. Yague, J.G.; Munoz, A.; de Monasterio-Schrader, P.; Defelipe, J.; Garcia-Segura, L.M.; Azcoitia, I. Aromatase expression in the human temporal cortex. Neuroscience 2006, 138, 389-401. [CrossRef] [PubMed]

30. Wozniak, A.; Hutchison, R.E.; Morris, C.M.; Hutchison, J.B. Neuroblastoma and Alzheimer's disease brain cells contain aromatase activity. Steroids 1998, 63, 263-267. [CrossRef]

31. Steckelbroeck, S.; Heidrich, D.D.; Stoffel-Wagner, B.; Hans, V.H.; Schramm, J.; Bidlingmaier, F.; Klingmuller, D. Characterization of aromatase cytochrome P450 activity in the human temporal lobe. J. Clin. Endocrinol. Metab. 1999, 84, 2795-2801. [CrossRef]

32. Ishunina, T.A.; van Beurden, D.; van der Meulen, G.; Unmehopa, U.A.; Hol, E.M.; Huitinga, I.; Swaab, D.F. Diminished aromatase immunoreactivity in the hypothalamus, but not in the basal forebrain nuclei in Alzheimer's disease. Neurobiol. Aging 2005, 26, 173-194. [CrossRef] [PubMed]

33. Steckelbroeck, S.; Watzka, M.; Reissinger, A.; Wegener-Toper, P.; Bidlingmaier, F.; Bliesener, N.; Hans, V.H.; Clusmann, H.; Ludwig, M.; Siekmann, L.; et al. Characterisation of estrogenic 17 $\beta$-hydroxysteroid dehydrogenase (17 $\beta-H S D)$ activity in the human brain. J. Steroid Biochem. Mol. Biol. 2003, 86, 79-92. [CrossRef]

34. Beyenburg, S.; Stoffel-Wagner, B.; Watzka, M.; Blumcke, I.; Bauer, J.; Schramm, J.; Bidlingmaier, F.; Elger, C.E. Expression of cytochrome P450scc mRNA in the hippocampus of patients with temporal lobe epilepsy. Neuroreport 1999, 10, 3067-3070. [CrossRef]

35. Watzka, M.; Bidlingmaier, F.; Schramm, J.; Klingmuller, D.; Stoffel-Wagner, B. Sex- and age-specific differences in human brain CYP11A1 mRNA expression. J. Neuroendocr. 1999, 11, 901-905. [CrossRef]

36. Luchetti, S.; Huitinga, I.; Swaab, D.F. Neurosteroid and GABA-A receptor alterations in Alzheimer's disease, Parkinson's disease and multiple sclerosis. Neuroscience 2011, 191, 6-21. [CrossRef] [PubMed]

37. Pike, C.J. Sex and the development of Alzheimer's disease. J. Neurosci. Res. 2017, 95, 671-680. [CrossRef] [PubMed]

38. Liere, P.; Schumacher, M. Mass spectrometric analysis of steroids: All that glitters is not gold. Expert Rev. Endocrinol. Metab. 2015, 10, 463-465. [CrossRef] [PubMed]

39. Weill-Engerer, S.; David, J.P.; Sazdovitch, V.; Liere, P.; Eychenne, B.; Pianos, A.; Schumacher, M.; Delacourte, A.; Baulieu, E.E.; Akwa, Y. Neurosteroid Quantification in Human Brain Regions: Comparison between Alzheimer's and Nondemented Patients. J. Clin. Endocrinol. Metab. 2002, 87, 5138-5143. [CrossRef]

40. Calan, O.G.; Akan, P.; Cataler, A.; Dogan, C.; Kocturk, S. Amyloid Beta Peptides Affect Pregnenolone and Pregnenolone Sulfate Levels in PC-12 and SH-SY5Y Cells Depending on Cholesterol. Neurochem. Res. 2016, 41, 1700-1712. [CrossRef]

41. Marx, C.E.; Trost, W.T.; Shampine, L.J.; Stevens, R.D.; Hulette, C.M.; Steffens, D.C.; Ervin, J.F.; Butterfield, M.I.; Blazer, D.G.; Massing, M.W.; et al. The neurosteroid allopregnanolone is reduced in prefrontal cortex in Alzheimer's disease. Biol. Psychiatry 2006, 60, 1287-1294. [CrossRef]

42. Naylor, J.C.; Kilts, J.D.; Hulette, C.M.; Steffens, D.C.; Blazer, D.G.; Ervin, J.F.; Strauss, J.L.; Allen, T.B.; Massing, M.W.; Payne, V.M.; et al. Allopregnanolone levels are reduced in temporal cortex in patients with Alzheimer's disease compared to cognitively intact control subjects. Biochim. Biophys. Acta 2010, 1801, 951-959. [CrossRef] [PubMed]

43. Liu, S.; Wu, H.; Xue, G.; Ma, X.; Wu, J.; Qin, Y.; Hou, Y. Metabolic alteration of neuroactive steroids and protective effect of progesterone in Alzheimer's disease-like rats. Neural Regen. Res. 2013, 8, 2800-2810. [PubMed]

44. Schaeffer, V.; Patte-Mensah, C.; Eckert, A.; Mensah-Nyagan, A.G. Modulation of neurosteroid production in human neuroblastoma cells by Alzheimer's disease key proteins. J. Neurobiol. 2006, 66, 868-881. [CrossRef] [PubMed]

45. Schaeffer, V.; Meyer, L.; Patte-Mensah, C.; Eckert, A.; Mensah-Nyagan, A.G. Dose-dependent and sequence-sensitive effects of amyloid-beta peptide on neurosteroidogenesis in human neuroblastoma cells. Neurochem. Int. 2008, 52, 948-955. [CrossRef] [PubMed] 
46. He, X.Y.; Wegiel, J.; Yang, S.Y. Intracellular oxidation of allopregnanolone by human brain type 1017 beta-hydroxysteroid dehydrogenase. Brain Res. 2005, 1040, 29-35. [CrossRef]

47. Luchetti, S.; Bossers, K.; Van de Bilt, S.; Agrapart, V.; Morales, R.R.; Frajese, G.V.; Swaab, D.F. Neurosteroid biosynthetic pathways changes in prefrontal cortex in Alzheimer's disease. Neurobiol. Aging 2011, 32, 1964-1976. [CrossRef]

48. Aitken, L.; Quinn, S.D.; Perez-Gonzalez, C.; Samuel, I.D.; Penedo, J.C.; Gunn-Moore, F.J. Morphology-Specific Inhibition of beta-Amyloid Aggregates by 17 beta-Hydroxysteroid Dehydrogenase Type 10. Chembiochem 2016, 17, 1029-1037. [CrossRef]

49. He, X.-Y.; Isaacs, C.; Yang, S.-Y. Roles of Mitochondrial 17 $\beta$-Hydroxysteroid Dehydrogenase Type 10 in Alzheimer's Disease. J. Alzheimers Dis. 2018, 62, 665-673. [CrossRef]

50. Rosario, E.R.; Chang, L.; Head, E.H.; Stanczyk, F.Z.; Pike, C.J. Brain levels of sex steroid hormones in men and women during normal aging and in Alzheimer's disease. Neurobiol. Aging 2011, 32, 604-613. [CrossRef]

51. Overk, C.R.; Perez, S.E.; Ma, C.; Taves, M.D.; Soma, K.K.; Mufson, E.J. Sex Steroid Levels and AD-Like Pathology in 3xTgAD Mice. J. Neuroendocr. 2013, 25, 131-144. [CrossRef] [PubMed]

52. Yue, X.; Lu, M.; Lancaster, T.; Cao, P.; Honda, S.; Staufenbiel, M.; Harada, N.; Zhong, Z.; Shen, Y.; Li, R. Brain estrogen deficiency accelerates Abeta plaque formation in an Alzheimer's disease animal model. Proc. Natl. Acad. Sci. USA 2005, 102, 19198-19203. [CrossRef]

53. Prange-Kiel, J.; Dudzinski, D.A.; Prols, F.; Glatzel, M.; Matschke, J.; Rune, G.M. Aromatase Expression in the Hippocampus of AD Patients and 5xFAD Mice. Neural Plast. 2016, 2016, 9802086. [CrossRef]

54. Garcia-Ovejero, D.; Azcoitia, I.; Doncarlos, L.L.; Melcangi, R.C.; Garcia-Segura, L.M. Glia-neuron crosstalk in the neuroprotective mechanisms of sex steroid hormones. Brain Res. Brain Res. Rev. 2005, 48, 273-286. [CrossRef] [PubMed]

55. Hiltunen, M.; Iivonen, S.; Soininen, H. Aromatase enzyme and Alzheimer's disease. Minerva Endocrinol. 2006, 31, 61-73. [PubMed]

56. Beam, C.R.; Kaneshiro, C.; Jang, J.Y.; Reynolds, C.A.; Pedersen, N.L.; Gatz, M. Differences Between Women and Men in Incidence Rates of Dementia and Alzheimer's Disease. J. Alzheimers Dis. 2018, 64, 1077-1083. [CrossRef] [PubMed]

57. Fisher, D.W.; Bennett, D.A.; Dong, H. Sexual dimorphism in predisposition to Alzheimer's disease. Neurobiol. Aging 2018, 70, 308-324. [CrossRef]

58. Nebel, R.A.; Aggarwal, N.T.; Barnes, L.L.; Gallagher, A.; Goldstein, J.M.; Kantarci, K.; Mallampalli, M.P.; Mormino, E.C.; Scott, L.; Yu, W.H.; et al. Understanding the impact of sex and gender in Alzheimer's disease: A call to action. Alzheimers Dement. 2018, 14, 1171-1183. [CrossRef]

59. Giatti, S.; Diviccaro, S.; Serafini, M.M.; Caruso, D.; Garcia-Segura, L.M.; Viviani, B.; Melcangi, R.C. Sex differences in steroid levels and steroidogenesis in the nervous system: Physiopathological role. Front. Neuroendocr. 2020, 56, 100804. [CrossRef]

60. Ferretti, M.T.; Iulita, M.F.; Cavedo, E.; Chiesa, P.A.; Schumacher Dimech, A.; Santuccione Chadha, A.; Baracchi, F.; Girouard, H.; Misoch, S.; Giacobini, E.; et al. Sex differences in Alzheimer disease - the gateway to precision medicine. Nat. Rev. Neurol. 2018, 14, 457-469. [CrossRef]

61. Corbo, R.M.; Gambina, G.; Broggio, E.; Scarabino, D.; Scacchi, R. Association study of two steroid biosynthesis genes (COMT and CYP17) with Alzheimer's disease in the Italian population. J. Neurol. Sci. 2014, 344, 149-153. [CrossRef] [PubMed]

62. Rosario, E.R.; Chang, L.; Stanczyk, F.Z.; Pike, C.J. Age-related testosterone depletion and the development of Alzheimer disease. JAMA 2004, 292, 1431-1432. [CrossRef] [PubMed]

63. Butler, H.T.; Warden, D.R.; Hogervorst, E.; Ragoussis, J.; Smith, A.D.; Lehmann, D.J. Association of the aromatase gene with Alzheimer's disease in women. Neurosci. Lett. 2010, 468, 202-206. [CrossRef] [PubMed]

64. Medway, C.; Combarros, O.; Cortina-Borja, M.; Butler, H.T.; Ibrahim-Verbaas, C.A.; de Bruijn, R.F.; Koudstaal, P.J.; van Duijn, C.M.; Ikram, M.A.; Mateo, I.; et al. The sex-specific associations of the aromatase gene with Alzheimer's disease and its interaction with IL10 in the Epistasis Project. Eur. J. Hum. Genet. 2014, 22, 216-220. [CrossRef] [PubMed]

65. Kancheva, R.; Hill, M.; Novak, Z.; Chrastina, J.; Kancheva, L.; Starka, L. Neuroactive steroids in periphery and cerebrospinal fluid. Neuroscience 2011, 191, 22-27. [CrossRef] [PubMed] 
66. Caruso, D.; Abbiati, F.; Giatti, S.; Romano, S.; Fusco, L.; Cavaletti, G.; Melcangi, R.C. Patients treated for male pattern hair with finasteride show, after discontinuation of the drug, altered levels of neuroactive steroids in cerebrospinal fluid and plasma. J. Steroid Biochem. Mol. Biol. 2015, 146, 74-79. [CrossRef]

67. Martin, J.J.; Plank, E.; Jungwirth, B.; Hapfelmeier, A.; Podtschaske, A.; Kagerbauer, S.M. Weak correlations between serum and cerebrospinal fluid levels of estradiol, progesterone and testosterone in males. BMC Neurosci. 2019, 20, 53. [CrossRef] [PubMed]

68. Schonknecht, P.; Pantel, J.; Klinga, K.; Jensen, M.; Hartmann, T.; Salbach, B.; Schroder, J. Reduced cerebrospinal fluid estradiol levels are associated with increased beta-amyloid levels in female patients with Alzheimer's disease. Neurosci. Lett. 2001, 307, 122-124. [CrossRef]

69. Yamazaki, Y.; Zhao, N.; Caulfield, T.R.; Liu, C.C.; Bu, G. Apolipoprotein E and Alzheimer disease: Pathobiology and targeting strategies. Nat. Rev. Neurol. 2019, 15, 501-518. [CrossRef]

70. Chernick, D.; Ortiz-Valle, S.; Jeong, A.; Qu, W.; Li, L. Peripheral versus central nervous system APOE in Alzheimer's disease: Interplay across the blood-brain barrier. Neurosci. Lett. 2019, 708, 134306. [CrossRef]

71. Jeong, W.; Lee, H.; Cho, S.; Seo, J. ApoE4-Induced Cholesterol Dysregulation and Its Brain Cell Type-Specific Implications in the Pathogenesis of Alzheimer's Disease. Mol. Cells 2019, 42, 739-746. [PubMed]

72. Altmann, A.; Tian, L.; Henderson, V.W.; Greicius, M.D.; Alzheimer's Disease Neuroimaging Initiative, I. Sex modifies the APOE-related risk of developing Alzheimer disease. Ann. Neurol. 2014, 75, 563-573. [CrossRef] [PubMed]

73. Buckley, R.F.; Mormino, E.C.; Amariglio, R.E.; Properzi, M.J.; Rabin, J.S.; Lim, Y.Y.; Papp, K.V.; Jacobs, H.I.L.; Burnham, S.; Hanseeuw, B.J.; et al. Sex, amyloid, and APOE epsilon4 and risk of cognitive decline in preclinical Alzheimer's disease: Findings from three well-characterized cohorts. Alzheimers Dement. 2018, 14, 1193-1203. [CrossRef] [PubMed]

74. Hogervorst, E.; Lehmann, D.J.; Warden, D.R.; McBroom, J.; Smith, A.D. Apolipoprotein E epsilon4 and testosterone interact in the risk of Alzheimer's disease in men. Int. J. Geriatr. Psychiatry 2002, 17, 938-940. [CrossRef] [PubMed]

75. Walsh, D.M.; Selkoe, D.J. Amyloid $\beta$-protein and beyond: The path forward in Alzheimer's disease. Curr. Opin. Neurobiol. 2020, 61, 116-124. [CrossRef]

76. Gursoy, E.; Cardounel, A.; Kalimi, M. Pregnenolone protects mouse hippocampal (HT-22) cells against glutamate and amyloid- $\beta$ protein toxicity. Neurochem. Res. 2001, 26, 15-21. [CrossRef]

77. Akan, P.; Kizildag, S.; Ormen, M.; Genc, S.; Oktem, M.A.; Fadiloglu, M. Pregnenolone protects the PC-12 cell line against amyloid $\beta$ peptide toxicity but its sulfate ester does not. Chem. Biol. Interact. 2009, 177, 65-70. [CrossRef]

78. El Bitar, F.; Meunier, J.; Villard, V.; Almeras, M.; Krishnan, K.; Covey, D.F.; Maurice, T.; Akwa, Y. Neuroprotection by the synthetic neurosteroid enantiomers ent-PREGS and ent-DHEAS against A $\beta 25-35$ peptide-induced toxicity in vitro and in vivo in mice. Psychopharmacol. (Berl.) 2014, 231, 3293-3312. [CrossRef]

79. Li, L.; Xu, B.; Zhu, Y.; Chen, L.; Sokabe, M.; Chen, L. DHEA prevents Abeta25-35-impaired survival of newborn neurons in the dentate gyrus through a modulation of PI3K-Akt-mTOR signaling. Neuropharmacology 2010, 59, 323-333. [CrossRef]

80. Qin, Y.; Chen, Z.; Han, X.; Wu, H.; Yu, Y.; Wu, J.; Liu, S.; Hou, Y. Progesterone attenuates Abeta (25-35)-induced neuronal toxicity via JNK inactivation and progesterone receptor membrane component 1-dependent inhibition of mitochondrial apoptotic pathway. J. Steroid Biochem. Mol. Biol. 2015, 154, 302-311. [CrossRef]

81. Carroll, J.C.; Rosario, E.R.; Villamagna, A.; Pike, C.J. Continuous and cyclic progesterone differentially interact with estradiol in the regulation of Alzheimer-like pathology in female 3xTransgenic-Alzheimer's disease mice. Endocrinology 2010, 151, 2713-2722. [CrossRef] [PubMed]

82. Jayaraman, A.; Carroll, J.C.; Morgan, T.E.; Lin, S.; Zhao, L.; Arimoto, J.M.; Murphy, M.P.; Beckett, T.L.; Finch, C.E.; Brinton, R.D.; et al. $17 \beta$-estradiol and progesterone regulate expression of $\beta$-amyloid clearance factors in primary neuron cultures and female rat brain. Endocrinology 2012, 153, 5467-5479. [CrossRef]

83. Mendell, A.L.; Chung, B.Y.T.; Creighton, C.E.; Kalisch, B.E.; Bailey, C.D.C.; MacLusky, N.J. Neurosteroid metabolites of testosterone and progesterone differentially inhibit ERK phosphorylation induced by amyloid beta in SH-SY5Y cells and primary cortical neurons. Brain Res. 2018, 1686, 83-93. [CrossRef] [PubMed] 
84. Bengtsson, S.K.; Johansson, M.; Backstrom, T.; Wang, M. Chronic allopregnanolone treatment accelerates Alzheimer's disease development in AbetaPP (Swe) PSEN1 (DeltaE9) mice. J. Alzheimers Dis. 2012, 31, 71-84. [CrossRef] [PubMed]

85. Bengtsson, S.K.; Johansson, M.; Backstrom, T.; Nitsch, R.M.; Wang, M. Brief but chronic increase in allopregnanolone cause accelerated AD pathology differently in two mouse models. Curr. Alzheimer Res. 2013, 10, 38-47.

86. Chen, S.; Wang, J.M.; Irwin, R.W.; Yao, J.; Liu, L.; Brinton, R.D. Allopregnanolone promotes regeneration and reduces $\beta$-amyloid burden in a preclinical model of Alzheimer's disease. PloS ONE 2011, 6, e24293. [CrossRef]

87. Rosario, E.R.; Carroll, J.C.; Oddo, S.; LaFerla, F.M.; Pike, C.J. Androgens regulate the development of neuropathology in a triple transgenic mouse model of Alzheimer's disease. J. Neurosci. 2006, 26, 13384-13389. [CrossRef]

88. Rosario, E.R.; Carroll, J.C.; Pike, C.J. Evaluation of the effects of testosterone and luteinizing hormone on regulation of $\beta$-amyloid in male 3xTg-AD mice. Brain Res. 2012, 1466, 137-145. [CrossRef]

89. Rosario, E.R.; Carroll, J.C.; Pike, C.J. Testosterone regulation of Alzheimer-like neuropathology in male 3xTg-AD mice involves both estrogen and androgen pathways. Brain Res. 2010, 1359, 281-290. [CrossRef] [PubMed]

90. Vegeto, E.; Villa, A.; Della Torre, S.; Crippa, V.; Rusmini, P.; Cristofani, R.; Galbiati, M.; Maggi, A.; Poletti, A. The Role of Sex and Sex Hormones in Neurodegenerative Diseases. Endocr Rev. 2020, 41, 1-47. [CrossRef]

91. Carroll, J.C.; Rosario, E.R.; Chang, L.; Stanczyk, F.Z.; Oddo, S.; LaFerla, F.M.; Pike, C.J. Progesterone and estrogen regulate Alzheimer-like neuropathology in female 3xTg-AD mice. J. Neurosci. 2007, 27, 13357-13365. [CrossRef] [PubMed]

92. Napolitano, M.; Costa, L.; Piacentini, R.; Grassi, C.; Lanzone, A.; Gulino, A. 17 $\beta$-estradiol protects cerebellar granule cells against $\beta$-amyloid-induced toxicity via the apoptotic mitochondrial pathway. Neurosci. Lett. 2014, 561, 134-139. [CrossRef]

93. Perianes-Cachero, A.; Canelles, S.; Aguado-Llera, D.; Frago, L.M.; Toledo-Lobo, M.V.; Carrera, I.; Cacabelos, R.; Chowen, J.A.; Argente, J.; Arilla-Ferreiro, E.; et al. Reduction in A $\beta$-induced cell death in the hippocampus of $17 \beta$-estradiol-treated female rats is associated with an increase in IGF-I signaling and somatostatinergic tone. J. Neurochem. 2015, 135, 1257-1271. [CrossRef] [PubMed]

94. Chong, F.P.; Ng, K.Y.; Koh, R.Y.; Chye, S.M. Tau Proteins and Tauopathies in Alzheimer's Disease. Cell Mol. Neurobiol. 2018, 38, 965-980. [CrossRef]

95. Dang, T.N.; Dobson-Stone, C.; Glaros, E.N.; Kim, W.S.; Hallupp, M.; Bartley, L.; Piguet, O.; Hodges, J.R.; Halliday, G.M.; Double, K.L.; et al. Endogenous progesterone levels and frontotemporal dementia: Modulation of TDP-43 and Tau levels in vitro and treatment of the A315T TARDBP mouse model. Dis. Model. Mech. 2013, 6, 1198-1204. [CrossRef] [PubMed]

96. Liu, X.A.; Zhu, L.Q.; Zhang, Q.; Shi, H.R.; Wang, S.H.; Wang, Q.; Wang, J.Z. Estradiol attenuates tau hyperphosphorylation induced by upregulation of protein kinase-A. Neurochem. Res. 2008, 33, 1811-1820. [CrossRef]

97. Majd, S.; Majd, Z.; Koblar, S.; Power, J. Beta estradiol and norepinephrine treatment of differentiated SH-SY5Y cells enhances tau phosphorylation at (Ser (396)) and (Ser (262)) via AMPK but not mTOR signaling pathway. Mol. Cell Neurosci. 2018, 88, 201-211. [CrossRef]

98. Shi, H.R.; Zhu, L.Q.; Wang, S.H.; Liu, X.A.; Tian, Q.; Zhang, Q.; Wang, Q.; Wang, J.Z. 17ß-estradiol attenuates glycogen synthase kinase- $3 \beta$ activation and tau hyperphosphorylation in Akt-independent manner. J. Neural. Transm. (Vienna) 2008, 115, 879-888. [CrossRef] [PubMed]

99. Buccarello, L.; Grignaschi, G.; Castaldo, A.M.; Di Giancamillo, A.; Domeneghini, C.; Melcangi, R.C.; Borsello, T. Sex Impact on Tau-Aggregation and Postsynaptic Protein Levels in the P301L Mouse Model of Tauopathy. J. Alzheimers Dis. 2017, 56, 1279-1292. [CrossRef]

100. Levine, A.J.; Hewett, L. Estrogen replacement therapy and frontotemporal dementia. Maturitas 2003, 45, 83-88. [CrossRef]

101. Swerdlow, R.H. Mitochondria and Mitochondrial Cascades in Alzheimer's Disease. J. Alzheimers Dis. 2018, 62, 1403-1416. [CrossRef] [PubMed]

102. Brown, R.C.; Han, Z.; Cascio, C.; Papadopoulos, V. Oxidative stress-mediated DHEA formation in Alzheimer's disease pathology. Neurobiol. Aging 2003, 24, 57-65. [CrossRef] 
103. Sinha, M.; Saha, A.; Basu, S.; Pal, K.; Chakrabarti, S. Aging and antioxidants modulate rat brain levels of homocysteine and dehydroepiandrosterone sulphate (DHEA-S): Implications in the pathogenesis of Alzheimer's disease. Neurosci. Lett. 2010, 483, 123-126. [CrossRef] [PubMed]

104. Saharan, S.; Mandal, P.K. The emerging role of glutathione in Alzheimer's disease. J. Alzheimers Dis. 2014, 40, 519-529. [CrossRef]

105. Pocernich, C.B.; Butterfield, D.A. Elevation of glutathione as a therapeutic strategy in Alzheimer disease. Biochim. Biophys. Acta 2012, 1822, 625-630. [CrossRef] [PubMed]

106. Yao, J.; Irwin, R.W.; Zhao, L.; Nilsen, J.; Hamilton, R.T.; Brinton, R.D. Mitochondrial bioenergetic deficit precedes Alzheimer's pathology in female mouse model of Alzheimer's disease. Proc. Natl. Acad. Sci. USA 2009, 106, 14670. [CrossRef] [PubMed]

107. Yao, J.; Irwin, R.; Chen, S.; Hamilton, R.; Cadenas, E.; Brinton, R.D. Ovarian hormone loss induces bioenergetic deficits and mitochondrial $\beta$-amyloid. Neurobiol. Aging 2012, 33, 1507-1521. [CrossRef]

108. Goguadze, N.; Zhuravliova, E.; Morin, D.; Mikeladze, D.; Maurice, T. Sigma-1 Receptor Agonists Induce Oxidative Stress in Mitochondria and Enhance Complex I Activity in Physiological Condition but Protect Against Pathological Oxidative Stress. Neurotox Res. 2019, 35, 1-18. [CrossRef]

109. Qian, X.; Cao, H.; Ma, Q.; Wang, Q.; He, W.; Qin, P.; Ji, B.; Yuan, K.; Yang, F.; Liu, X.; et al. Allopregnanolone attenuates A $325-35$-induced neurotoxicity in PC12 cells by reducing oxidative stress. Int. J. Clin. Exp. Med. 2015, 8, 13610-13615.

110. Costa, A.R.; Marcelino, H.; Goncalves, I.; Quintela, T.; Tomas, J.; Duarte, A.C.; Fonseca, A.M.; Santos, C.R. Sex Hormones Protect Against Amyloid-beta Induced Oxidative Stress in the Choroid Plexus Cell Line Z310. J. Neuroendocr. 2016, 28. [CrossRef]

111. Irwin, R.W.; Yao, J.; Hamilton, R.T.; Cadenas, E.; Brinton, R.D.; Nilsen, J. Progesterone and estrogen regulate oxidative metabolism in brain mitochondria. Endocrinology 2008, 149, 3167-3175. [CrossRef] [PubMed]

112. Gaignard, P.; Liere, P.; Therond, P.; Schumacher, M.; Slama, A.; Guennoun, R. Role of Sex Hormones on Brain Mitochondrial Function, with Special Reference to Aging and Neurodegenerative Diseases. Front. Aging Neurosci. 2017, 9, 406. [CrossRef] [PubMed]

113. Grimm, A.; Lim, Y.-A.; Mensah-Nyagan, A.G.; Götz, J.; Eckert, A. Alzheimer's Disease, Oestrogen and Mitochondria: An Ambiguous Relationship. Mol. Neurobiol. 2012, 46, 151-160. [CrossRef]

114. Olivieri, G.; Novakovic, M.; Savaskan, E.; Meier, F.; Baysang, G.; Brockhaus, M.; Muller-Spahn, F. The effects of beta-estradiol on SHSY5Y neuroblastoma cells during heavy metal induced oxidative stress, neurotoxicity and beta-amyloid secretion. Neuroscience 2002, 113, 849-855. [CrossRef]

115. Wang, X.; Dykens, J.A.; Perez, E.; Liu, R.; Yang, S.D.; Covey, D.F.; Simpkins, J.W. Neuroprotective Effects of $17 \beta$-Estradiol and Nonfeminizing Estrogens against $\mathrm{H}_{2} \mathrm{O}_{2}$ Toxicity in Human Neuroblastoma SK-N-SH Cells. Mol. Pharm. 2006, 70, 395-404. [CrossRef] [PubMed]

116. Duong, P.; Tenkorang, M.A.A.; Trieu, J.; McCuiston, C.; Rybalchenko, N.; Cunningham, R.L. Neuroprotective and neurotoxic outcomes of androgens and estrogens in an oxidative stress environment. Biol. Sex. Differ. 2020, 11, 12. [CrossRef]

117. Schuessel, K.; Leutner, S.; Cairns, N.J.; Muller, W.E.; Eckert, A. Impact of gender on upregulation of antioxidant defence mechanisms in Alzheimer's disease brain. J. Neural. Transm. (Vienna) 2004, 111, 1167-1182.

118. Vina, J.; Lloret, A. Why women have more Alzheimer's disease than men: Gender and mitochondrial toxicity of amyloid-beta peptide. J. Alzheimers Dis. 2010, 20 (Suppl. 2), S527-S533. [CrossRef]

119. Ransohoff, R.M. How neuroinflammation contributes to neurodegeneration. Science 2016, 353, 777-783. [CrossRef]

120. Webers, A.; Heneka, M.T.; Gleeson, P.A. The role of innate immune responses and neuroinflammation in amyloid accumulation and progression of Alzheimer's disease. Immunol. Cell Biol. 2020, 98, $28-41$. [CrossRef]

121. Singh, A.K.; Mishra, G.; Maurya, A.; Awasthi, R.; Kumari, K.; Thakur, A.; Rai, A.; Rai, G.K.; Sharma, B.; Kulkarni, G.T.; et al. Role of TREM2 in Alzheimer's Disease and its Consequences on beta- Amyloid, Tau and Neurofibrillary Tangles. Curr. Alzheimer Res. 2019, 16, 1216-1229. [CrossRef] [PubMed]

122. Hashemiaghdam, A.; Mroczek, M. Microglia heterogeneity and neurodegeneration: The emerging paradigm of the role of immunity in Alzheimer's disease. J. Neuroimmunol. 2020, 341, 577185. [CrossRef] [PubMed] 
123. Hong, Y.; Wang, X.; Sun, S.; Xue, G.; Li, J.; Hou, Y. Progesterone exerts neuroprotective effects against Abeta-induced neuroinflammation by attenuating ER stress in astrocytes. Int. Immunopharmacol. 2016, 33, 83-89. [CrossRef] [PubMed]

124. Uchoa, M.F.; Moser, V.A.; Pike, C.J. Interactions between inflammation, sex steroids, and Alzheimer's disease risk factors. Front. Neuroendocr. 2016, 43, 60-82. [CrossRef] [PubMed]

125. Vegeto, E.; Belcredito, S.; Ghisletti, S.; Meda, C.; Etteri, S.; Maggi, A. The endogenous estrogen status regulates microglia reactivity in animal models of neuroinflammation. Endocrinology 2006, 147, 2263-2272. [CrossRef]

126. Li, R.; Shen, Y.; Yang, L.B.; Lue, L.F.; Finch, C.; Rogers, J. Estrogen enhances uptake of amyloid beta-protein by microglia derived from the human cortex. J. Neurochem. 2000, 75, 1447-1454. [CrossRef]

127. Yun, J.; Yeo, I.J.; Hwang, C.J.; Choi, D.Y.; Im, H.S.; Kim, J.Y.; Choi, W.R.; Jung, M.H.; Han, S.B.; Hong, J.T. Estrogen deficiency exacerbates $A \beta$-induced memory impairment through enhancement of neuroinflammation, amyloidogenesis and NF-kB activation in ovariectomized mice. Brain Behav. Immun. 2018, 73, 282-293. [CrossRef]

128. Yao, P.L.; Zhuo, S.; Mei, H.; Chen, X.F.; Li, N.; Zhu, T.F.; Chen, S.T.; Wang, J.M.; Hou, R.X.; Le, Y.Y. Androgen alleviates neurotoxicity of beta-amyloid peptide $(A \beta)$ by promoting microglial clearance of $A \beta$ and inhibiting microglial inflammatory response to A $\beta$. CNS Neurosci. Ther. 2017, 23, 855-865. [CrossRef]

129. Laurent, C.; Buee, L.; Blum, D. Tau and neuroinflammation: What impact for Alzheimer's Disease and Tauopathies? Biomed. J. 2018, 41, 21-33. [CrossRef]

130. Terada, T.; Yokokura, M.; Obi, T.; Bunai, T.; Yoshikawa, E.; Ando, I.; Shimada, H.; Suhara, T.; Higuchi, M.; Ouchi, Y. In vivo direct relation of tau pathology with neuroinflammation in early Alzheimer's disease. J. Neurol. 2019, 266, 2186-2196. [CrossRef]

131. Bellucci, A.; Westwood, A.J.; Ingram, E.; Casamenti, F.; Goedert, M.; Spillantini, M.G. Induction of inflammatory mediators and microglial activation in mice transgenic for mutant human P301S tau protein. Am. J. Pathol. 2004, 165, 1643-1652. [CrossRef]

132. Bellucci, A.; Bugiani, O.; Ghetti, B.; Spillantini, M.G. Presence of reactive microglia and neuroinflammatory mediators in a case of frontotemporal dementia with P301S mutation. Neurodegener. Dis. 2011, 8, 221-229. [CrossRef] [PubMed]

133. Perea, J.R.; Avila, J.; Bolos, M. Dephosphorylated rather than hyperphosphorylated Tau triggers a pro-inflammatory profile in microglia through the p38 MAPK pathway. Exp. Neurol. 2018, 310, 14-21. [CrossRef] [PubMed]

134. Bennett, R.E.; Bryant, A.; Hu, M.; Robbins, A.B.; Hopp, S.C.; Hyman, B.T. Partial reduction of microglia does not affect tau pathology in aged mice. J. Neuroinflammation 2018, 15, 311. [CrossRef] [PubMed]

135. Romero-Molina, C.; Navarro, V.; Sanchez-Varo, R.; Jimenez, S.; Fernandez-Valenzuela, J.J.; Sanchez-Mico, M.V.; Munoz-Castro, C.; Gutierrez, A.; Vitorica, J.; Vizuete, M. Distinct Microglial Responses in Two Transgenic Murine Models of TAU Pathology. Front. Cell Neurosci. 2018, 12, 421. [CrossRef] [PubMed]

136. Gatt, A.; Lee, H.; Williams, G.; Thuret, S.; Ballard, C. Expression of neurogenic markers in Alzheimer's disease: A systematic review and metatranscriptional analysis. Neurobiol. Aging 2019, 76, 166-180. [CrossRef] [PubMed]

137. Xu, B.; Yang, R.; Chang, F.; Chen, L.; Xie, G.; Sokabe, M. Neurosteroid PREGS protects neurite growth and survival of newborn neurons in the hippocampal dentate gyrus of APPswe/PS1dE9 mice. Curr. Alzheimer Res. 2012, 9, 361-372. [CrossRef] [PubMed]

138. Irwin, R.W.; Wang, J.M.; Chen, S.; Brinton, R.D. Neuroregenerative mechanisms of allopregnanolone in Alzheimer's disease. Front. Endocrinol. (Lausanne) 2011, 2, 117. [CrossRef]

139. Mahmoud, R.; Wainwright, S.R.; Galea, L.A. Sex hormones and adult hippocampal neurogenesis: Regulation, implications, and potential mechanisms. Front. Neuroendocr. 2016, 41, 129-152. [CrossRef]

140. Ponti, G.; Farinetti, A.; Marraudino, M.; Panzica, G.; Gotti, S. Sex Steroids and Adult Neurogenesis in the Ventricular-Subventricular Zone. Front. Endocrinol. (Lausanne) 2018, 9, 156. [CrossRef]

141. Zheng, J.Y.; Liang, K.S.; Wang, X.J.; Zhou, X.Y.; Sun, J.; Zhou, S.N. Chronic Estradiol Administration During the Early Stage of Alzheimer's Disease Pathology Rescues Adult Hippocampal Neurogenesis and Ameliorates Cognitive Deficits in Aß1-42 Mice. Mol. Neurobiol. 2017, 54, 7656-7669. [CrossRef] [PubMed]

142. Chen, Y.; Fu, A.K.Y.; Ip, N.Y. Synaptic dysfunction in Alzheimer's disease: Mechanisms and therapeutic strategies. Pharmacology 2019, 195, 186-198. [CrossRef] [PubMed] 
143. Yang, R.; Zhou, R.; Chen, L.; Cai, W.; Tomimoto, H.; Sokabe, M.; Chen, L. Pregnenolone sulfate enhances survival of adult-generated hippocampal granule cells via sustained presynaptic potentiation. Neuropharmacology 2011, 60, 529-541. [CrossRef] [PubMed]

144. Smith, C.; Gibbs, T.; Farb, D. Pregnenolone sulfate as a modulator of synaptic plasticity. Psychopharmacology 2014, 231, 3537-3556. [CrossRef]

145. Shimizu, H.; Ishizuka, Y.; Yamazaki, H.; Shirao, T. Allopregnanolone increases mature excitatory synapses along dendrites via protein kinase A signaling. Neuroscience 2015, 305, 139-145. [CrossRef]

146. Clements, L.; Harvey, J. Activation of oestrogen receptor $\alpha$ induces a novel form of LTP at hippocampal temporoammonic-CA1 synapses. Br. J. Pharm. 2020, 177, 642-655. [CrossRef]

147. Hara, Y.; Crimins, J.L.; Puri, R.; Wang, A.C.J.; Motley, S.E.; Yuk, F.; Ramos, T.M.; Janssen, W.G.M.; Rapp, P.R.; Morrison, J.H. Estrogen Alters the Synaptic Distribution of Phospho-GluN2B in the Dorsolateral Prefrontal Cortex While Promoting Working Memory in Aged Rhesus Monkeys. Neuroscience 2018, 394, 303-315. [CrossRef]

148. Hatanaka, Y.; Hojo, Y.; Mukai, H.; Murakami, G.; Komatsuzaki, Y.; Kim, J.; Ikeda, M.; Hiragushi, A.; Kimoto, T.; Kawato, S. Rapid increase of spines by dihydrotestosterone and testosterone in hippocampal neurons: Dependence on synaptic androgen receptor and kinase networks. Brain Res. 2015, 1621, 121-132. [CrossRef]

149. Fattoretti, P.; Malatesta, M.; Mariotti, R.; Zancanaro, C. Testosterone administration increases synaptic density in the gyrus dentatus of old mice independently of physical exercise. Exp. Gerontol. 2019, 125, 110664. [CrossRef]

150. Merlo, S.; Spampinato, S.F.; Capani, F.; Sortino, M.A. Early $\beta$-Amyloid-induced Synaptic Dysfunction Is Counteracted by Estrogen in Organotypic Hippocampal Cultures. Curr. Alzheimer Res. 2016, 13, 631-640. [CrossRef]

151. Lau, C.F.; Ho, Y.S.; Hung, C.H.; Wuwongse, S.; Poon, C.H.; Chiu, K.; Yang, X.; Chu, L.W.; Chang, R.C. Protective effects of testosterone on presynaptic terminals against oligomeric beta-amyloid peptide in primary culture of hippocampal neurons. Biomed. Res. Int. 2014, 2014, 103906. [CrossRef] [PubMed]

152. Kirova, A.M.; Bays, R.B.; Lagalwar, S. Working memory and executive function decline across normal aging, mild cognitive impairment, and Alzheimer's disease. Biomed. Res. Int. 2015, 2015, 748212. [CrossRef] [PubMed]

153. Webster, S.J.; Bachstetter, A.D.; Nelson, P.T.; Schmitt, F.A.; Van Eldik, L.J. Using mice to model Alzheimer's dementia: An overview of the clinical disease and the preclinical behavioral changes in 10 mouse models. Front. Genet. 2014, 5, 88. [CrossRef] [PubMed]

154. Maurice, T.; Su, T.P.; Privat, A. Sigma1 ( $\sigma 1)$ receptor agonists and neurosteroids attenuate $\beta 25-35$-amyloid peptide-induced amnesia in mice through a common mechanism. Neuroscience 1998, 83, 413-428. [CrossRef]

155. Yang, R.; Chen, L.; Wang, H.; Xu, B.; Tomimoto, H. Anti-amnesic effect of neurosteroid PREGS in A $\beta 25-35$-injected mice through $\sigma 1$ receptor- and $\alpha 7 \mathrm{nAChR}$-mediated neuroprotection. Neuropharmacology 2012, 63, 1042-1050. [CrossRef]

156. Frye, C.A.; Walf, A.A. Effects of progesterone administration and APPswe+PSEN1Deltae9 mutation for cognitive performance of mid-aged mice. Neurobiol. Learn. Mem. 2008, 89, 17-26. [CrossRef]

157. Singh, C.; Liu, L.; Wang, J.M.; Irwin, R.W.; Yao, J.; Chen, S.; Henry, S.; Thompson, R.F.; Brinton, R.D. Allopregnanolone restores hippocampal-dependent learning and memory and neural progenitor survival in aging 3xTgAD and nonTg mice. Neurobiol. Aging 2012, 33, 1493-1506. [CrossRef]

158. Dye, R.V.; Miller, K.J.; Singer, E.J.; Levine, A.J. Hormone replacement therapy and risk for neurodegenerative diseases. Int. J. Alzheimers Dis. 2012, 2012, 258454. [CrossRef]

159. Jimenez-Rubio, G.; Herrera-Perez, J.J.; Hernandez-Hernandez, O.T.; Martinez-Mota, L. Relationship between androgen deficiency and memory impairment in aging and Alzheimer's disease. Actas Esp. Psiquiatr. 2017, $45,227-247$.

160. Osmanovic-Barilar, J.; Salkovic-Petrisi, M. Evaluating the Role of Hormone Therapy in Postmenopausal Women with Alzheimer's Disease. Drugs Aging 2016, 33, 787-808. [CrossRef]

161. Arbo, B.D.; Ribeiro, M.F.; Garcia-Segura, L.M. Development of new treatments for Alzheimer's disease based on the modulation of translocator protein (TSPO). Ageing Res. Rev. 2019, 54, 100943. [CrossRef] [PubMed]

162. Papadopoulos, V.; Fan, J.; Zirkin, B. Translocator protein $(18 \mathrm{kDa})$ : An update on its function in steroidogenesis. J. Neuroendocr. 2018, 30. [CrossRef] 
163. Liere, P.; Pianos, A.; Oudinet, J.-P.; Schumacher, M.; Akwa, Y. Differential effects of the 18-kDa translocator protein (TSPO) ligand etifoxine on steroidogenesis in rat brain, plasma and steroidogenic glands: Pharmacodynamic studies. Psychoneuroendocrinology 2017, 83, 122-134. [CrossRef]

164. Janssen, B.; Vugts, D.J.; Funke, U.; Molenaar, G.T.; Kruijer, P.S.; van Berckel, B.N.; Lammertsma, A.A.; Windhorst, A.D. Imaging of neuroinflammation in Alzheimer's disease, multiple sclerosis and stroke: Recent developments in positron emission tomography. Biochim. Biophys. Acta 2016, 1862, 425-441. [CrossRef] [PubMed]

165. Guilarte, T.R. TSPO in diverse CNS pathologies and psychiatric disease: A critical review and a way forward. Pharmacol. Ther. 2019, 194, 44-58. [CrossRef] [PubMed]

166. Da Pozzo, E.; Giacomelli, C.; Barresi, E.; Costa, B.; Taliani, S.; Passetti Fda, S.; Martini, C. Targeting the 18-kDa translocator protein: Recent perspectives for neuroprotection. Biochem. Soc. Trans. 2015, 43, 559-565. [CrossRef]

167. Arbo, B.D.; Marques, C.V.; Ruiz-Palmero, I.; Ortiz-Rodriguez, A.; Ghorbanpoor, S.; Arevalo, M.A.; Garcia-Segura, L.M.; Ribeiro, M.F. 4'-Chlorodiazepam is neuroprotective against amyloid- $\beta$ through the modulation of survivin and bax protein expression in vitro. Brain Res. 2016, 1632, 91-97. [CrossRef]

168. Lejri, I.; Grimm, A.; Halle, F.; Abarghaz, M.; Klein, C.; Maitre, M.; Schmitt, M.; Bourguignon, J.J.; Mensah-Nyagan, A.G.; Bihel, F.; et al. TSPO Ligands Boost Mitochondrial Function and Pregnenolone Synthesis. J. Alzheimers Dis. 2019, 72, 1045-1058. [CrossRef]

169. Grimm, A.; Lejri, I.; Halle, F.; Schmitt, M.; Gotz, J.; Bihel, F.; Eckert, A. Mitochondria modulatory effects of new TSPO ligands in a cellular model of tauopathies. J. Neuroendocr. 2020, 32, e12796. [CrossRef]

170. Barron, A.M.; Garcia-Segura, L.M.; Caruso, D.; Jayaraman, A.; Lee, J.W.; Melcangi, R.C.; Pike, C.J. Ligand for translocator protein reverses pathology in a mouse model of Alzheimer's disease. J. Neurosci. 2013, 33, 8891-8897. [CrossRef]

171. Christensen, A.; Pike, C.J. TSPO ligand PK11195 improves Alzheimer-related outcomes in aged female 3xTg-AD mice. Neurosci. Lett. 2018, 683, 7-12. [CrossRef] [PubMed]

(C) 2020 by the author. Licensee MDPI, Basel, Switzerland. This article is an open access article distributed under the terms and conditions of the Creative Commons Attribution (CC BY) license (http://creativecommons.org/licenses/by/4.0/). 